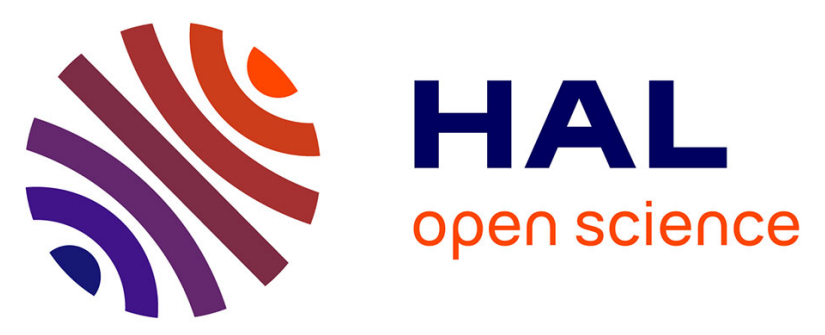

\title{
Application of neural network model for the prediction of Chromium concentration in phytoremediated contaminated soils
}

Nour Hattab, Ridha Hambli, Mikael Motelica-Heino, Xavier Bourrat

\section{- To cite this version:}

Nour Hattab, Ridha Hambli, Mikael Motelica-Heino, Xavier Bourrat. Application of neural network model for the prediction of Chromium concentration in phytoremediated contaminated soils. Journal of Geochemical Exploration, 2013, 128, pp.25-34. 10.1016/j.gexplo.2013.01.005 . insu-00783032

HAL Id: insu-00783032

https://hal-insu.archives-ouvertes.fr/insu-00783032

Submitted on 27 Mar 2013

HAL is a multi-disciplinary open access archive for the deposit and dissemination of scientific research documents, whether they are published or not. The documents may come from teaching and research institutions in France or abroad, or from public or private research centers.
L'archive ouverte pluridisciplinaire HAL, est destinée au dépôt et à la diffusion de documents scientifiques de niveau recherche, publiés ou non, émanant des établissements d'enseignement et de recherche français ou étrangers, des laboratoires publics ou privés. 


\title{
Application of neural network model for the prediction of Chromium concentration in phytoremediated contaminated soils
}

\author{
Nour HATTAB $^{\mathrm{a}^{*}}$, Ridha HAMBLI ${ }^{\mathrm{b}}$, Mikael MOTELICA-HEINO ${ }^{\mathrm{a}}$, Xavier BOURRAT $^{\mathrm{a}}$, \\ Michel MENCH ${ }^{\mathrm{C}}$
}

${ }^{\mathrm{a}}$ ISTO

UMR 7327 - CNRS/Université d'Orléans

Campus Géosciences, 1A, rue de la Férollerie, 45071 Orléans cedex 2, France

mail : nour.hattab@univ-orleans.fr

${ }^{\mathrm{b}}$ Prisme Institute $-\mathrm{MMH}$

8, Rue Léonard de Vinci, 45072 Orléans cedex 2, France

mail : $\underline{\text { ridha.hambli@univ-orleans.fr }}$

${ }^{\mathrm{c}}$ UMR BIOGECO INRA 1202, Ecologie des communautés, Université Bordeaux 1, Bat B8 RDC Est, Avenue des facultés, F-33405 Talence, France

\section{Abstract}

The assessment of chromium concentrations in plants requires the quantification of a large number of soil factors that affect their potential availability and subsequent toxicity and a mathematical model that predicts their relative concentrations. Many soil characteristics can change the availability of chromium $(\mathrm{Cr})$ to plants in soils. However, accurate, rapid and simple predictive models of metal concentrations are still lacking in soil and plant analysis. In the present work a novel artificial neural network (ANN) model was developed as an alternative rapid and accurate tool for the prediction of $\mathrm{Cr}$ concentration in dwarf bean leaves grown in the laboratory on phytoremediated contaminated soils treated with different amendments. First, sixteen $(4 \mathrm{x} 4)$ soil samples were harvested from a phytoremediated contaminated site located in south-western France. Second, a series of measurements were performed on the soil samples. The inputs are the soil amendment, the soil $\mathrm{pH}$, the soil electrical conductivity and the dissolved organic carbon of the soil and the output is the concentration of $\mathrm{Cr}$ in the dwarf bean 
leaves. Third, an ANN model was developed and its performance was evaluated using a test data set and then applied to predict the exposition of the bean leaves to the $\mathrm{Cr}$ concentration versus the soil inputs. The performance of the ANN method was compared with the traditional multi linear regressions method using the training and test data sets. The results of this study show that the ANN model trained on experimental measurements can be successfully applied to the rapid prediction of plant exposition to $\mathrm{Cr}$.

Key words: Artificial neural networks (ANN), Soil contamination, Chromium prediction, pH, EC, DOC

\section{Introduction}

Chromium in plants has received relatively little attention from researchers in comparison with other trace elements such as $\mathrm{Cu}, \mathrm{Cd}, \mathrm{Ni}, \mathrm{Al}$ and As. Soils contaminated with Cr have serious consequences for terrestrial ecosystems, agricultural production and human health (Adriano, 2001). Chromium has been considered as the $16^{\text {th }}$ most toxic pollutant and it has become a serious health concern because of its carcinogenic and teratogenic effects (Kowalski, 1994). Chromium is also considered a serious environmental pollutant (Kotas and Stasicka, 2000), due to its widespread use in the metallurgical and chemical industries. Improper disposal, poor storage and leakage of $\mathrm{Cr}$ from waste discharge through the soil can release $\mathrm{Cr}$ to the environment, causing contamination of groundwater and adverse biological and ecological effects.

Chromium is present in the environment in the form of $\mathrm{Cr}(\mathrm{III})$ and $\mathrm{Cr}(\mathrm{VI})$. These two forms show different chemical, physico-chemical and biochemical properties. Species of $\mathrm{Cr}(\mathrm{VI})$ are more soluble, more mobile, more bioavailable and more toxic than $\mathrm{Cr}(\mathrm{III})$ (Murti et 
al., 1989; Katz and Salem, 1994; Fendorf, 1995; James et al., 1997). This may be due to the fact that $\mathrm{Cr}(\mathrm{VI})$ penetrates mammalian cells more readily than $\mathrm{Cr}$ (III) (Wetterhahn and Hamilton, 1989). Compounds of $\mathrm{Cr}(\mathrm{VI})$ are toxic at low concentrations for both plants and animals. The presence of $\mathrm{Cr}(\mathrm{VI})$ in water, soil and wastewater has, therefore, been of great concern. Many factors can influence its migration process, such as $\mathrm{pH}$ (McLean and Bledsoe, 1992), dissolved organic carbon or DOC (Heijerick et al., 2003), electrical conductivity or EC (Förstner. 1985) and soil characteristics such as cation exchange capacity, clay content and competition from other metal ions (Sauerbeck and Hein, 1991; Smith, 1994). Soluble chromates are converted to insoluble $\mathrm{Cr}$ (III) salts and the subsequent availability for plants decreases (Wetterhahn and Hamilton, 1989). However, soil amendments such as pH (KabataPendias et al.. 2000; Jackson et al., 2000), DOC (Hsu et al., 2000), and EC (Laing et al., 2009; Hatje et al., 2003) can be used to change the soil condition and reduce the high concentration of $\mathrm{Cr}$ in contaminated soils (Mench and Bes, 2009; Bes and Mench, 2008). Amendments that induce solubility can be used to clean polluted sites by leaching the contaminating trace elements or by facilitating their uptake by plants (phytoextraction) (Kolbas et al., 2011).

Quantifying Cr mobility in a given soil is a critical aspect of predicting its toxicity. Since performing experimental measurements to investigate the relationship between soil parameters and $\mathrm{Cr}$ mobility in soil is time-consuming, difficult and expensive, the development of models simulating soil processes has increased rapidly in recent years (Minasny and McBratney, 2002). Generally two common methods are used to develop prediction models, regression methods and artificial neural networks (ANN). Several multiple linear regression (MLR) models have been developed over the past 20 years to predict the sorption of trace metals in soils (van der Zee and van Riemsdijk, 1987; Andersen and Christensen, 1988; Reinds et al., 1995; Streck and Richter, 1997; Römkens and Salomons, 1998; Tiktak et al., 1998; Elzinga et al., 1999; Schug et al., 2000). With MLR methods, the relationships between soil 
inputs (properties) and soil output characteristics have to be stated a priori in the regression models. An alternative to MLR is the application of ANN models where such relationships do not need to be formulated beforehand (Anagu et al., 2009; Sarmadian and Taghizadeh Mehrjardi, 2008; Schaap and Leij, 1998; Hambli et al., 2006; Hambli, 2009; Minasny et al., 2004; McBratney et al., 2003; Behrens et al., 2005; Buszewski and Kowalkowski, 2006; Gandhimathi and Meenambal, 2012).

It has been reported that ANNs provide superior predictive performance compared to conventional mathematical methods including MLR models (van der Zee and van Riemsdijk, 1987; Andersen and Christensen, 1988; Streck and Richter, 1997; Römkens and Salomons, 1998; Tiktak et al., 1998; Schaap and Lei, 1998; Elzinga et al., 1999; Sarmadian and Taghizadeh Mehrjardi, 2008). In regression models in many soil engineering situations, the input-output relationships are highly complex and are not well understood. The lack of physical understanding and of a powerful general tool for mathematical modeling leads to either simplifying the problem or incorporating several assumptions into mathematical models. Consequently, many mathematical models fail to simulate the complex behavior of most soil engineering problems.

ANNs have been widely used in the field of soil science for prediction of soil hydraulic properties (Schaap et al., 1998; Minasny et al., 2004) generation of digital soil maps (McBratney et al., 2003; Behrens et al., 2005) and modeling of the behavior of trace metals (Buszewski and Kowalkowski, 2006; Anagu et al., 2009; Gandhimathi and Meenambal, 2012). In the cases, ANN are trained to find model input-output relations using an iterative calibration process (training phase). Moreover, ANNs have the advantage of not imposing restrictions on inputs and outputs and can be easily applied to carry out inverse calculation (Jenkins, 1997; Rafiq et al., 2001; Hambli et al., 2006). 
In the present study, a novel ANN model was developed as an alternative rapid and accurate tool for the prediction of $\mathrm{Cr}$ concentration in dwarf bean leaves (BL) grown in the laboratory on phytostabilized contaminated soils treated with different amendments. The inputs are soil amendment, soil $\mathrm{pH}$, soil EC and soil DOC, whereas the output is Cr concentration in the dwarf BL. The performance of the ANN method was compared with a traditional MLR method using the same training and test data sets. The comparative study revealed that ANN provided a better performance than MLR method in predicting soil properties. Results showed that the neural network model led to a very rapid and accurate prediction of the soil outputs.

\section{Material and Methods}

\subsection{Site, soil sampling and soil characterization}

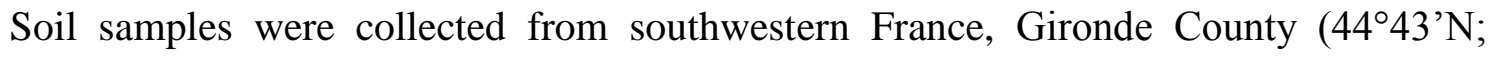
$\left.0^{\circ} 30^{`} \mathrm{~W}\right)$. This site has been contaminated with high concentrations of copper sulfate and chromated copper arsenate. The history of the site and the origin of these pollutants are described in detail by Mench and Bes (2009).

The study site is divided into 15 sub-sites labeled A to E and P1 to P10 depending on total topsoil $\mathrm{Cu}$ concentration (Fig. 1a) (Mench and Bes, 2009; Bes et al, 2010). Long-term phytostabilization experiments have been established at the P3 and P7 sub-sites by Bes et al. (2008); Mench and Bes (2009). Plant communities in the zone of the field trial included Agrostis capillaris, Elytrigia repens, Rumex acetosella, Portulaca oleracea, Hypericum perforatum, Hypochaeris radicata, Euphorbia chamaescyce, Echium vulgare, Agrostis stolonifera, Lotus corniculatus, Cerastium glomeratum, and Populus nigra (Bes et al. 2010). The field trial zone $\left(150 \mathrm{~m}^{2}\right)$ was established at site P3, which consists of two plots; that were further divided into $16(3 \mathrm{~m} \times 1 \mathrm{~m})$ sub-plots (Fig. 1b). On these 16 sub-plots, four different 
amendments were applied, one per subplot (Latin square design) and carefully mixed in the top soil $(0-0.30 \mathrm{~m})$ with a stainless steel spade with four replicates: untreated soil (UNT), $0.2 \%$ of dolomite limestone (DL), 5\% of compost of poultry manure and pine bark (CPM), and a mixture of $0.2 \%$ DL and 5\% CPM (DLX CPM). Sixteen soil samples (four replicates) were collected from the four plots treated with the different amendments (4X (UNT), 4X (DL), 4X $(\mathrm{OM})$ and $4 \mathrm{X}(\mathrm{DLX} \mathrm{OM}))$ to a depth of $0.25 \mathrm{~m}$ (Fig. 1b).

Soil $\mathrm{pH}(7.0 \pm 0.23)$ was measured in a 1:1 soil:water suspension using a glass electrode $\mathrm{pH}$ meter (Jackson, 1967). Total nitrogen $\left(0.534 \mathrm{mg} \mathrm{kg}^{-1}\right)$ was determined at the INRA Laboratoire d'Analyses des sols (LAS), Arras, France using standard methods (INRA LAS, 2007). The organic matter content was determined by a modified Walkely-Blak method: $0.5 \mathrm{~g}$ soil was placed in a $500 \mathrm{ml}$ conical flask and mixed with $10 \mathrm{ml}$ of $0.17 \mathrm{M} \mathrm{K}_{2} \mathrm{Cr}_{2} \mathrm{O}_{7}$, followed by addition of $20 \mathrm{ml}$ of $\mathrm{H}_{2} \mathrm{SO}_{4}, 200 \mathrm{ml}$ of water, $10 \mathrm{ml}$ of $\mathrm{H}_{3} \mathrm{PO}_{4}$ and $1 \mathrm{ml}$ of diphenylamine indicator. Finally, the contents were titrated with $0.5 \mathrm{M} \mathrm{FeSO}_{4} \cdot 7 \mathrm{H}_{2} 0$. The main characteristics of site P3 (0-0.25 m soil layer) are given in Table 1 . The cation exchange capacity (CEC) (3.49 Cmol+/kg) was determined using cobaltihexamine chloride (Ciesielski and Sterckeman, 1997). Total metal content in P3 site was determined by ICP-AES after wet digestion with $\mathrm{HF}$ and $\mathrm{HCIO}_{4}$ (AFNOR NF X 31-147; Ciesielski et al., 1997) (Table 1, column 2). Total soil metal concentrations were in the common range of French sandy soil for $\mathrm{Cr}$, As and $\mathrm{Zn}$, but total soil $\mathrm{Cu}$ was in excess for these coarse sandy soils (Table 1, column 3). Total $\mathrm{Cr}$ concentrations in each of the 16 potted soil samples were measured by laser ablation inductively coupled plasma-mass spectrometry (LA-ICP-MS). Prior to metal content measurements, the accuracy of the metals determination was checked by performing calibrations with a homogeneous combination of certified reference materials such as NIST610 (artificial glass), GOR-128-G (komatiite natural glass) and NIST-361 (steel). Little difference was found between the measured and the reference results. In our case, the LA-ICP- 
MS measurements produced an averaged error in the range of $-1.2 \%$ to $1.17 \%$. After the calibration phase, 4 repeated measurements were performed for each soil generating 64 testing results ( 4 soils $\times 4$ amendments $\times 4$ replicates). The precision of the metal content measurement was assessed by the standard deviation (SD) and the coefficient of variation (COV) (Table 2).
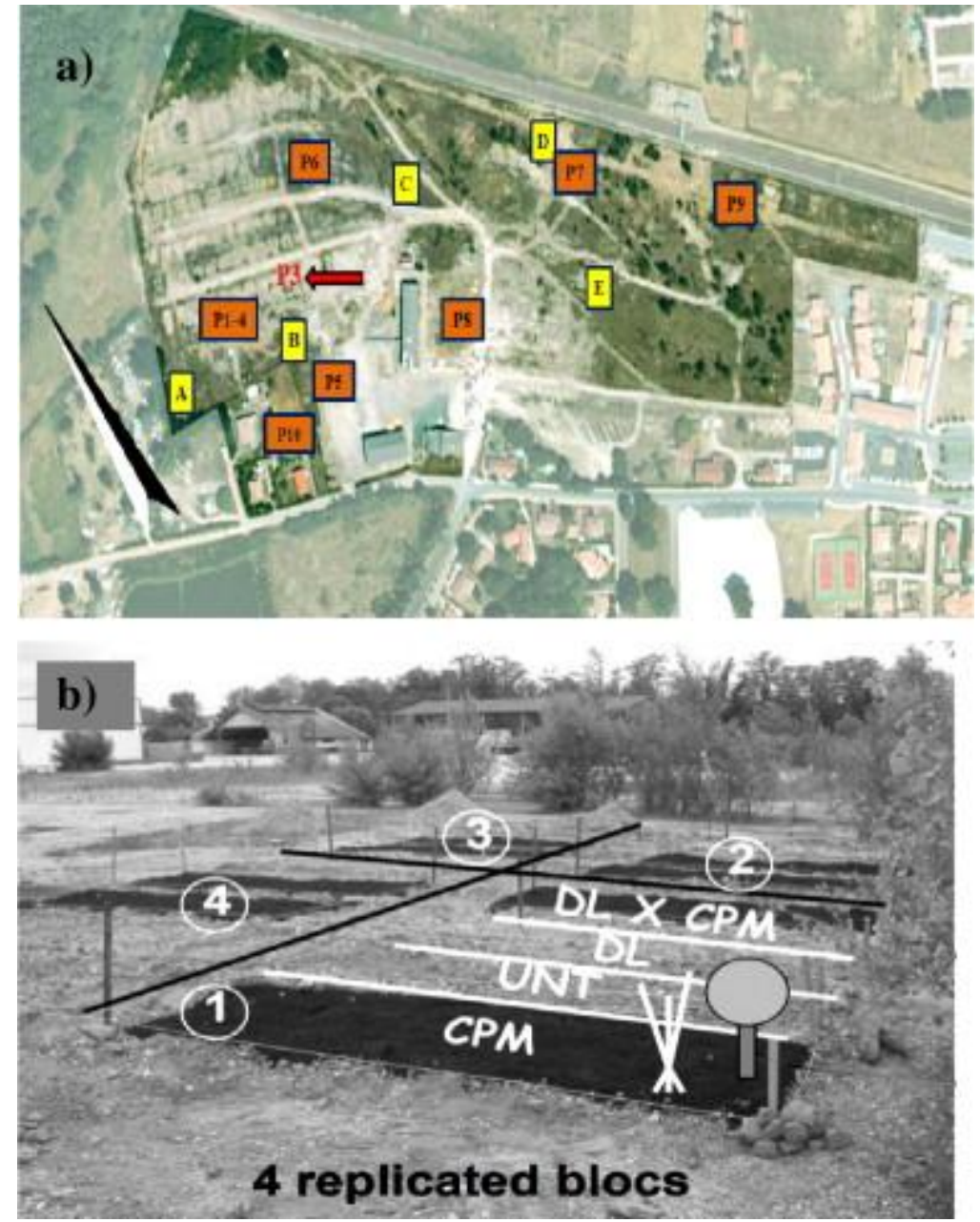

Fig. 1. a) Location of studied sites from A to E. The arrows indicate the studied site P3 (adapted from Mench and Bes, 2009). b) The two plots of soil with the different types of amendment (adapted from Bes, 2008). 
Table 1. Main characteristics of site P3 (0-0.25 m soil layer).

\section{Parameters Site P3 Background values in French sandy soils ${ }^{\mathbf{a}}$}

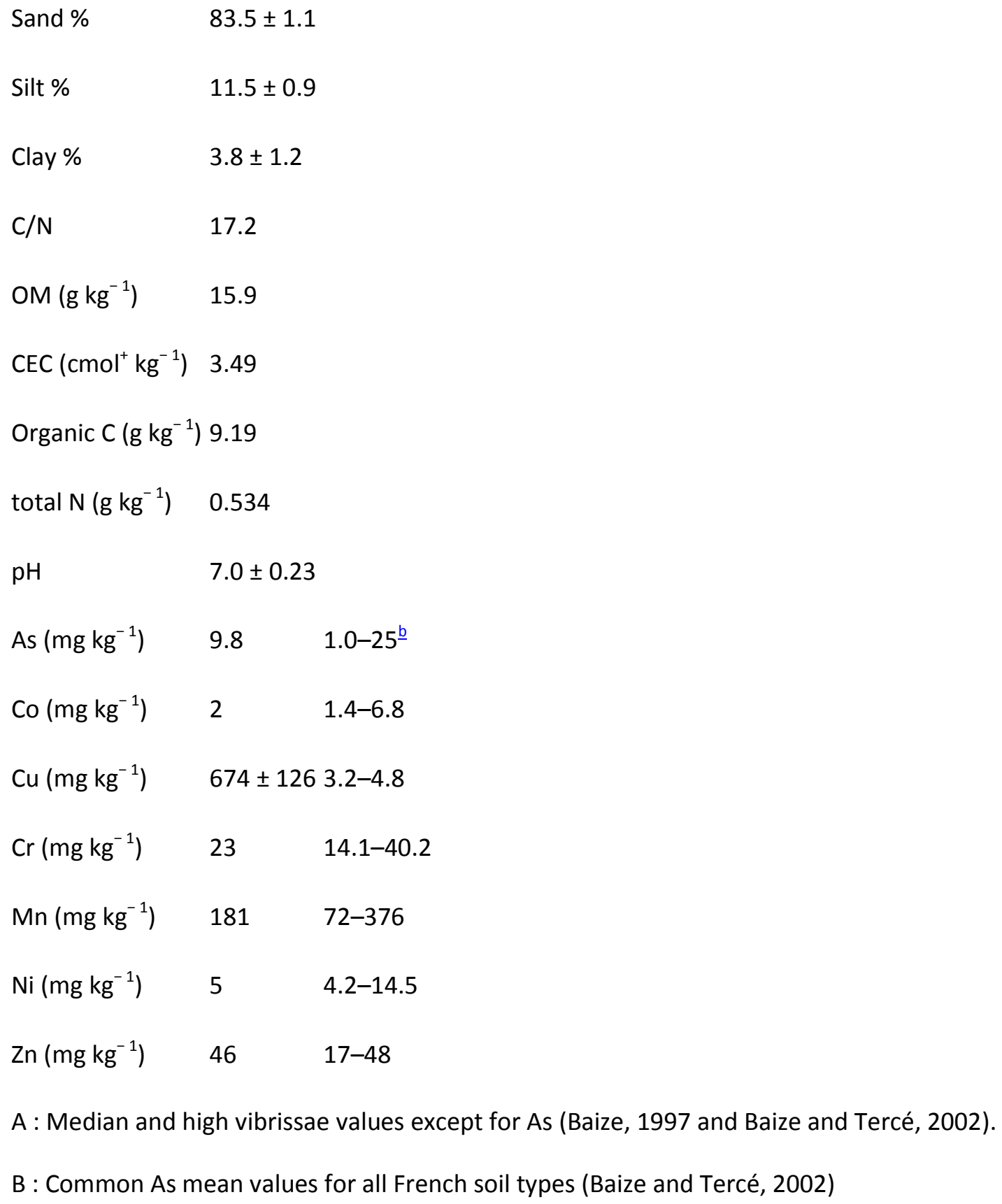


Table 2. The experimental values ( $\mathrm{pH}, \mathrm{EC}, \mathrm{DOC}$ and $\mathrm{Cr}$ ). Four replications were performed for each measurement generating 64 testing results ( 4 soils $\times 4$ amendments $\times 4$ replicates) allowing for the determination of the mean values, standard deviations (SD) and coefficient of variations (COV).

\begin{tabular}{|c|c|c|c|c|c|c|c|c|c|}
\hline $\begin{array}{c}\text { Soil } \\
\text { reference }\end{array}$ & Amendments & $\begin{array}{c}\text { Mean } \\
\mathrm{pH}\end{array}$ & $\begin{array}{l}\text { SD- } \\
\text { COV } \\
(\%)\end{array}$ & $\begin{array}{l}\text { Mean EC } \\
\left(\mu \mathrm{S} \mathrm{cm}^{-1}\right)\end{array}$ & $\begin{array}{l}\text { SD- } \\
\text { COV } \\
(\%)\end{array}$ & $\begin{array}{c}\text { Mean } \\
\text { DOC } \\
\left(\mathrm{mg} \mathrm{I}^{-1}\right)\end{array}$ & $\begin{array}{l}\text { SD- } \\
\text { COV } \\
(\%)\end{array}$ & $\begin{array}{c}\text { Mean } \mathrm{Cr} \\
\text { concentration } \\
\text { in the soil } \\
\left(\mathrm{mg} \mathrm{kg}^{-1}\right)\end{array}$ & $\begin{array}{l}\text { SD- } \\
\text { COV } \\
(\%)\end{array}$ \\
\hline B1-1 & UNT & $\begin{array}{l}7.12 \\
\text { NS }\end{array}$ & & 1114 NS & & $15.93^{\square}$ & & $15.97^{\square \square}$ & \\
\hline B2-8 & UNT & $\begin{array}{l}7.31 \\
\text { NS }\end{array}$ & & $1230 \mathrm{NS}$ & & 14.34 & & $16.21^{\square}$ & \\
\hline & & 728 & $\begin{array}{l}0.15- \\
2.08 \%\end{array}$ & & $\begin{array}{l}214.7- \\
18.31 \%\end{array}$ & & $\begin{array}{l}4.01- \\
7.75 \%\end{array}$ & & $\begin{array}{l}0.98- \\
6.30 \%\end{array}$ \\
\hline B3-15 & UNT & $\begin{array}{l}1.28 \\
\mathrm{NS}\end{array}$ & & 917 NS & & 21.74 & & $15.81^{\square \square}$ & \\
\hline B4-10 & UNT & $\begin{array}{l}6.99 \\
\text { NS }\end{array}$ & & 1430 NS & & $24.32^{\square}$ & & $14.07^{\square}$ & \\
\hline B1-2 & CPM & $\begin{array}{l}6.98 \\
\text { NS }\end{array}$ & & 1018 NS & & 27.08 & & $14.67^{\square}$ & \\
\hline B2-5 & CPM & $\begin{array}{l}7.60 \\
\text { NS }\end{array}$ & & 884 NS & & 20.64 & & $15.03^{\square}$ & \\
\hline B3-16 & CPM & $\begin{array}{l}7.46 \\
\text { NS }\end{array}$ & $\begin{array}{l}0.27- \\
3.67 \%\end{array}$ & 771 NS & $\begin{array}{l}122- \\
14.24 \%\end{array}$ & $25.85^{\square}$ & $\begin{array}{l}4.50- \\
5.44 \%\end{array}$ & $15.15^{\square \square}$ & $\begin{array}{l}0.34- \\
2.31 \%\end{array}$ \\
\hline B4-11 & CPM & $\begin{array}{l}7.26 \\
\text { NS }\end{array}$ & & 754 NS & & 33.99 & & $14.40^{\square}$ & \\
\hline B1-4 & DL & $\begin{array}{l}7.49 \\
\text { NS }\end{array}$ & & 1654 NS & & 26.34 & & $17.16^{\square \square}$ & \\
\hline B2-7 & DL & $\begin{array}{l}7.67 \\
\text { NS }\end{array}$ & $\begin{array}{l}0.14- \\
1.87 \%\end{array}$ & 1000 NS & $\begin{array}{l}308.3- \\
24.79 \%\end{array}$ & 25.76 & $\begin{array}{l}4.14- \\
6.96 \%\end{array}$ & 16.98 & $\begin{array}{l}0.11- \\
0.66 \%\end{array}$ \\
\hline B3-14 & DL & $\begin{array}{l}7.43 \\
\text { NS }\end{array}$ & & 1013 NS & & $26.52^{\square}$ & & $17.13^{\square \square}$ & \\
\hline
\end{tabular}




\begin{tabular}{|c|c|c|c|c|c|c|c|c|c|}
\hline $\begin{array}{c}\text { Soil } \\
\text { reference }\end{array}$ & Amendments & $\begin{array}{c}\text { Mean } \\
\mathrm{pH}\end{array}$ & $\begin{array}{l}\text { SD- } \\
\text { Cov } \\
(\%)\end{array}$ & $\begin{array}{l}\text { Mean EC } \\
\left(\mu \mathrm{cm}^{-1}\right)\end{array}$ & $\begin{array}{l}\text { SD- } \\
\text { COV } \\
(\%)\end{array}$ & $\begin{array}{c}\text { Mean } \\
\text { DOC } \\
\left(\mathrm{mg} \mathrm{I}^{-1}\right)\end{array}$ & $\begin{array}{l}\text { SD- } \\
\text { COV } \\
(\%)\end{array}$ & $\begin{array}{c}\text { Mean } \mathrm{Cr} \\
\text { concentration } \\
\text { in the soil } \\
\left(\mathrm{mg} \mathrm{kg}^{-1}\right)\end{array}$ & $\begin{array}{l}\text { SD- } \\
\text { COV } \\
(\%)\end{array}$ \\
\hline B4-9 & $\mathrm{DL}$ & $\begin{array}{l}7.34 \\
\text { NS }\end{array}$ & & 1308 NS & & $38.46^{\square}$ & & $16.93^{\square}$ & \\
\hline B1-3 & DLX CPM & $\begin{array}{l}7.45 \\
\text { NS }\end{array}$ & & 1192 NS & & $33.12^{\square}$ & & 16.09 & \\
\hline B2-6 & DLX CPM & $\begin{array}{l}7.00 \\
\text { NS }\end{array}$ & & 1347 NS & & 34.26 & & $15.91^{\square \square}$ & \\
\hline & & 707 & $\begin{array}{l}0.32- \\
4.46 \%\end{array}$ & & $\begin{array}{l}152.2- \\
11.90 \%\end{array}$ & & $\begin{array}{l}2.50- \\
7.02 \%\end{array}$ & & $\begin{array}{l}0.2- \\
1.27 \%\end{array}$ \\
\hline B3-13 & DLX CPM & NS & & 1457 NS & & $29.16^{\square}$ & & $15.93^{\square}$ & \\
\hline B4-12 & DLX CPM & $\begin{array}{l}7.59 \\
\text { NS }\end{array}$ & & 1119 NS & & $29.75^{\square}$ & & $16.35^{\square \square}$ & \\
\hline
\end{tabular}

NS (non significant).

Significant for $\mathrm{p}<0.05$.

?ㅁ

Highly significant for $\mathrm{p}<0.001$.

\subsection{Germination tests}

A phyto-toxicological test was applied to the 16 soil samples to assess whether the use of amendments on the field trial zone, assisted by phytostabilisation, is able to reduce the concentrations of bioavailable fractions of $\mathrm{Cr}$ for plants. To achieve this objective, one kilo of each soil (4X (UNT), 4X (DL), 4X (OM), 4X (DLX OM)) was placed in a pot after sieving (2 
$\mathrm{mm}$ ). Then, four seeds of dwarf beans (Phaseolus vulgaris) were sowed in each potted soil and cultivated for 18 days in controlled conditions (16 h light/8 h darkness). Soil moisture was maintained at around $50 \%$ of the field water capacity with additions of deionized water after weighing. Then, the soil moisture was raised to $80 \%$ (11-13\% of air-dried soil mass) at the beginning of the germination stage of the grains. At the end of the growing period, the plants were harvested and then the dry weights of roots, shoots, and primary leaves were determined after drying at $70 \mathrm{C}^{\circ}$.

The dwarf beans were weighed (35-150 $\mathrm{mg})$ directly into Savillex polytetrafluoroethylene PTFE $50 \mathrm{ml}$ vessels. To each vessel $2 \mathrm{ml} \mathrm{H}_{2} \mathrm{O}$ and $2 \mathrm{ml}$ supra-pure 14 $\mathrm{M} \mathrm{HNO}_{3}$ were added and the vessels were heated open at $65{ }^{\circ} \mathrm{C}$ for $2 \mathrm{~h}$. Then, the vessel caps were closed and the containers were left overnight at $65{ }^{\circ} \mathrm{C}(12-14 \mathrm{~h})$. After that they were opened, $0.5 \mathrm{ml}$ of $\mathrm{H}_{2} \mathrm{O}_{2}(30 \%)$ was added to each sample and left at $75{ }^{\circ} \mathrm{C}$ open for $3 \mathrm{~h}$. Then, $1.5 \pm 0.5 \mathrm{ml}$ of fluorhydric acid HF (48\%) was added to each sample, vessel caps were closed and the samples were left at $100{ }^{\circ} \mathrm{C}$ overnight. Then, vessels were opened and kept at $120{ }^{\circ} \mathrm{C}$

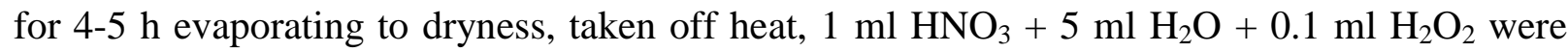
added to each vessel, gently warmed up and after cooling down made up to $50 \mathrm{ml}$. Trace element concentrations in digests were determined by ICP-MS (Varian 810-MS) using standard solution of measured trace elements, in our case, Reference Standard Solution of Chromium (1000ppm $\pm 1 \% /$ Certified) was used. The accuracy of the metals determination was checked by performing calibrations with standard reference solution. Strong correlation was found between the measured and the reference results $\left(R^{2}=0.998\right)$. After the calibration phase, 4 repeated measurements were performed for each digest generating 64 testing results $(4$ repeated $\times 16$ digests). The precision of the metal content measurement was assessed by the standard deviation (SD) (Table 4), then the Cr concentration in a given dry weight, expressed here, the 
mineral masses (g per pot) were determined by multiplying $\mathrm{Cr}$ concentration in the $\mathrm{BL}$ (mg.kg-1) in dry weight of BL (g DW) (Table 4).

\subsection{Characterization of soil solution}

After harvesting the dwarf beans, the soils were watered with distilled water, and maintained daily at $80 \%$ of field capacity (11-13\% of air-dried soil mass) for 15 days. After 15 days, three Rhizon soil-moisture samplers from Rhizosphere Research Products (Wageningen, Holland) were inserted for $24 \mathrm{~h}$ with a $45^{\circ}$ angle into each potted soil ( $4 \times 16$ soil) to collect (30 $\mathrm{ml}$ ) of soil solution from each pot. DOC was analyzed in the solution of soils by a Shimadzu ${ }^{\odot}$ TOC 5000A analyzer. Before DOC measurements, the accuracy of the analyzer was checked by performing calibration with standard reference solution (potassium hydrogen phthalate (KHP) (1000 $\mathrm{mg} \mathrm{C/L})$ ). In our case, the measurements produced an $\mathrm{R}^{2}=0.999$. After the calibration, 4 repeated measurements of DOC were performed for each soil solution. The precision of the DOC measurement was assessed by the SD and the COV (Table 2). Soil pH and EC were determined in the same soil solutions by $\mathrm{pH}$ meter and the EC meter (Table 2).

Measured soil variables included soil $\mathrm{pH}$, soil EC, DOC and $\mathrm{Cr}$ concentration in the BL with 4 replications for each measurement $(4 \times 4$ measurements) for the ANN training. Then, a neural network model was developed and trained to predict the exposition of the BL to the high Cr concentration in the soil. The inputs are the soil amendment, soil pH, soil EC and DOC. The output is $\mathrm{Cr}$ concentration in the BL.

\subsection{Selection of soil factors}


The mobility of trace elements plays a major role in the behavior and transfer of metals in soils. Mobility, availability and/or bioavailability of metals is controlled by several factors such as the soil's chemical and physical properties $(\mathrm{pH}, \mathrm{EC}, \mathrm{DOC}$, temperature, ion charges, etc.), plant species and their related factors (Soon and Bates, 1982; Sauerbeck and Hein, 1991; Davies, 1992, Smith, Fisher, 2002; Weng et al., 2002; Kerndorff, and Schnitzer; 1980; Vogeler et al., 2009). It has been reported that the relationships between the mobility of metal concentrations in plants and a given soil are mainly influenced by the soil properties related to the ion charges (Fisher, 2002; Weng et al., 2002; Kerndorffand Schnitzer; 1980; Vogeler et al., 2009). Therefore, in the current preliminary study, the soil inputs for the ANN model were limited to the three measurable factors considered to be the most influential ( $\mathrm{pH}, \mathrm{DOC}$ and EC) on the mobility and availability of metals in the soil.

Kabata-Pendias et al., (2000) and Jackson et al., (2000) reported that the addition of amendments to soil increased the soil $\mathrm{pH}$ compared to the untreated soil, leading to a reduction in the mobility and the availability of metals to plants. The second variable used in our work was DOC. Hsu et al. (2000) noted that the addition of amendment to the soil increased the soil DOC compared to that of untreated soil, which led to increasing plant mass, reducing the bioavailability of metals by forming ligands with dissolved organic matter. The third parameter was EC. Du Laing et al. (2008, 2009) and Hatje et al. (2003) found that an increase in conductivity (salinity) led to increasing the mobility of some metals such as $\mathrm{Cd}$ and $\mathrm{Zn}$, thereby increasing the availability and bioavailability of these metals to plants.

To prepare the training data for the ANN, 64 different measurements (4 soils $\times 4$ amendments $\times 4$ replicates) were performed on the four different soils subjected to four different treatments (UNT, DL, CPM and DLX CPM). Because of the noise (uncertainty) concerning the inputs measurement which can be characterized by a given a set of scattered 
input data, the 64 experiments were used for the training phase instead of 16 (the total number of experimental replicates) to ensure a more robust processing of the scattered measurements (Table 2).

The 64 experiments were used for the training phase instead of 16 (the total number of experimental replicates) to ensure a more robust processing of the scattered measurements. Presenting the entire patterns (64) ensured the reduction of the ANN prediction sensitivity to noise related to inputs (Velleman, 1980; Kafadar, 1994; Hambli, 2009). The inputs and their minimum/maximum levels are given in Table 3.

Table 3. Selected inputs and output for ANN training $(\mathrm{UNT}=\# 1, \mathrm{CPM}=\# 2, \mathrm{DL}=\# 3$, DLX CPM = \#4).

Inputs Level Min value Max value

$\begin{array}{llll}\text { Soil treatment } & 4 & \# 1 & \# 4 \\ \mathrm{pH} & 4 & 6.98 & 7.6 \\ \mathrm{EC}\left(\mu \mathrm{S} \mathrm{cm}^{-1}\right) & 4 & 754 & 1654 \\ \text { DOC }\left(\mathrm{mg} \mathrm{l}^{-1}\right) & 4 & 14.337 & 34.260 \\ \text { Output } & \\ \text { Cr concentration in the bean leaves }\left(\mathrm{mg} \mathrm{kg}^{-1}\right)\end{array}$

\subsection{Statistical analysis}

The total soil solution concentrations of $\mathrm{Cr}, \mathrm{pH}, \mathrm{DOC}, \mathrm{EC}$, foliar elemental concentrations, foliar mineral masses of elements and leaf dry weight (DW) yields were statistically analyzed by ANOVA (Statistica) to evaluate the influence of the treatment and the different effects of soil variables on each other. All analytical determinations were performed in four replicates. Differences were considered statistically significant at $\mathrm{p}<0.05$. 


\subsection{Artificial neural network}

The ANN architecture is composed of an input layer, a certain number of hidden layers and an output layer in forward connections. Each neuron in the input layer represents a single input parameter. These values are directly transmitted to the subsequent neurons of the hidden layers. The neurons of the last layer represent the ANN outputs (Fig. 2).

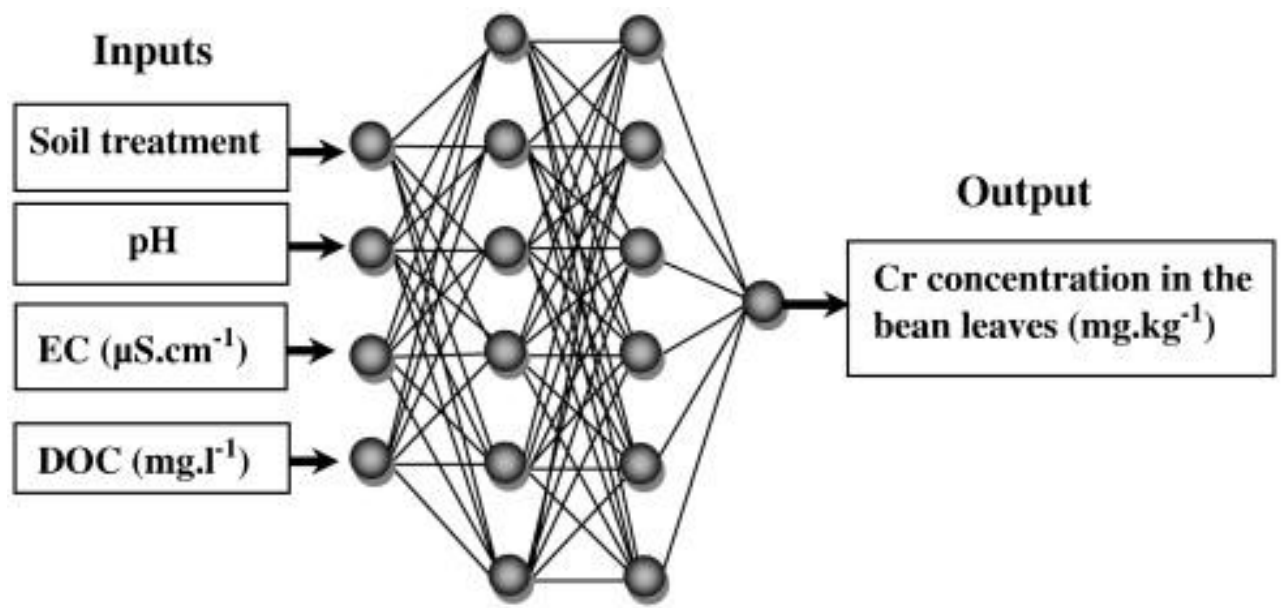

Fig. 2. Neural network architecture composed of four input layers, two hidden layers and one output layer.

The output $y_{i}^{m}$ of neuron $i$ in a layer $m$ is calculated by (Jenkins, 1997; Rafiq et al., 2001; Hambli et al., 2006):

$$
\begin{aligned}
y_{i}^{m} & =f\left(v_{i}^{m}\right) \\
v_{i}^{m} & =\sum_{j=1}^{L} w_{j i}^{m-1} y_{j}^{m-1}+b_{i}^{m}
\end{aligned}
$$


where $y_{i}^{0}$ are the model inputs, $v_{i}^{m}$ are the outputs of the layer $m, f$ is the activation function, $L$ is the number of connections to the previous layer, $w_{j i}^{m-1}$ corresponds to the weights of each connection and $b_{i}^{m}$ is the bias, representing the constant part of the activation function.

Among activation functions, the sigmoid (logistic) function is the one most usually employed in ANN applications. It is given by (Jenkins, 1997; Rafiq et al., 2001; Hambli et al., 2006):

$$
f\left(v_{i}^{m}\right)=\frac{1}{1+\exp \left(-\theta v_{i}^{m}\right)}
$$

where $\theta$ is a parameter defining the slope of the function $(\theta=0.9)$.

The training process in ANNs involves presenting a set of examples (input patterns) with known outputs (target output) (Jenkins, 1997; Rafiq et al., 2001; Hambli et al., 2006; Hambli, 2009). The system adjusts the $w_{j i}^{m-1}$ of the internal connections to minimize errors between the network output and target output (Levenberg-Marquardt back-propagation or BP training algorithm in the current work). The knowledge is represented and stored by the strength (weights) of the connections between the neurons.

In the present work, an in-house ANN program called Neuromod written in Fortran (Hambli et al., 2006; Hambli, 2009) was applied. The basic ANN configuration employed in this study has a double hidden layer with six neurons of each layer with a learning rate factor $\eta=0.1$ and momentum coefficient $\alpha=0.1$ (Fig. 2). The learning rate coefficient $\eta$ and the momentum term $\alpha$ are two user-defined BP algorithm training parameters that affect the learning procedure of the ANN. The training is sensitive to the choice of these net parameters. The learning rate coefficient, employed during the adjustment of $w_{j i}^{m-1}$, was used to speed up or slow down the learning process. A larger learning coefficient increases the weight changes, hence large steps 
are taken towards the global minimum of error level, while smaller learning coefficients increase the number of steps taken to reach the desired error level. Tests performed for more than two hidden layers and different $\eta$ and $\alpha$ parameters showed no significant improvement in the obtained results.

A total of 64 measurements were performed. The proportion of ANN training set from the available data ranged generally from $25 \%$ to $80 \%$. The proportion of ANN testing set from the available data is about 15 to $20 \%$ and the proportion of the validation data set is about ( 5 to 15\%) (Haykin, 2009). In the current work, the experimental data (64 cases) were subdivided in three sets: $62.5 \%$ of the data were used for training (40), $25 \%$ for testing (16) and $12.5 \%$ for validation (8) covering a wide range of the experiments for validation (2 samples from every experiment variant). The testing data were not used for training. The testing data provided cross validation during the ANN training for verification of the network prediction accuracy. The validation data were used to measure the performance of the predictive capability of the ANN after complete training.

In order to avoid data saturation and artifacts related mainly to the coding of the amendments (non-numeric data), the input and output variables were normalized between 0 and 1 using:

$$
x_{i}^{\text {norm }}=\frac{x_{i}-x_{i}^{\min }}{x_{i}^{\max }-x_{i}^{\min }}
$$

where $x_{i}, x_{i}^{\min }, x_{i}^{\max }$ and $x_{i}^{\text {norm }}$ denote, respectively, values of input (output) variables $i$, minimum value of input (output) variable, maximum value of input (output) variable and the normalized value of $i$.

The de-normalized value of the ANN was computed using:

$$
y_{t}=y_{\text {min }}+y_{\text {norm }}\left(y_{\text {max }}-y_{\text {min }}\right)
$$


where $y_{t}, y_{\min }, y_{\max }$ and $y_{\text {norm }}$ are, respectively, real-valued output variable, minimum and maximum values of real-valued output and the normalized output value from the neural- ANN model.

\subsubsection{Coding of the amendments}

The amendments are model independent inputs, therefore, they can be represented using sequential codes (integer) as a non-numeric indexes from 1 to 4 (UNT=\#1, CPM=\#2, DL=\#3, DLX CPM=\#4). Such non-numeric data encoding is common when applying ANN models (Haykin, 2009). An alternative approach is to use the one-of-N encoding technique, which consists of transforming a many-state variable (four states in our case) into several binary variables (one for each state) to represent a single nominal variable. The number of numeric variables equals the number of possible values; one of the $N$ variables is set to one, and the others are set to zero. In the current case, the input variable "amendment" was replaced by 4 binary variables, (e.g., $\mathrm{UNT}=1000, \mathrm{DL}=0100, \mathrm{CPM}=0010, \mathrm{DLX} \mathrm{CPM}=0001$; where 0 denotes to inactive and 1 active (Ruggiero, 1997)).

In certain cases, a nominal variable with a large number of states would require a prohibitive number of numeric variables for one-of-N encoding, which can increase considerably the ANN size and making the training difficult. If such is the case, it is possible to model the nominal variable using a single numeric sequential encoding if these non-numeric data are inputs. These sequential codes are not quantities or values related to the treatments or any classification of them. In the current ANN model, these codes are treated by the ANN algorithm in the following general form:

- In case \#1 (UNT amendment), the prediction model is determined by the ANN learning phase related to the case 1 representing the UNT treatment. 
- In case \#2 (CPM amendment), the prediction model is determined by the ANN learning phase related to the case 2 representing the CPM treatment.

○ In case \#3 (DL amendment), the prediction model is determined by the ANN learning phase related to the case 3 representing the DL treatment.

- In case \#4 (DLX CPM amendment), the prediction model is determined by the ANN learning phase related to the case 4 representing the DLX CPM treatment.

In addition, during the training phase the assigned codes for the amendments $[1,4]$ are converted in the normalized range $[0,1]$ using Eq. (4) to avoid coding artificial effects and de-normalized after prediction in the range of $[1,4]$ using Eq. (5).

\subsection{Multiple linear regression model}

The most common method used to quantify relationships between inputs and outputs is to employ multiple linear regressions in the form:

$$
Y_{i}=\alpha_{i}+\sum_{j=1}^{n} \beta_{i} X_{i}
$$

where $Y_{i}$ is the output variable $i, X_{i}$ are the input variables related to the sample, $i, \alpha_{i}$ and $\beta_{i}$ are the model regression coefficients determined by a fitting procedure using generally least squares method.

\section{Results and Discussion}

\subsection{Experimental results}




\subsubsection{Soil solution characteristics}

Table 2 shows the physico-chemical parameters (i.e., $\mathrm{pH}$, DOC and EC) of the 16 soil solutions and the total soil $\mathrm{Cr}$ concentration measured in the 16 contaminated soils. These measurements concerned the 16 pots containing the 16 types of soils: $4 \mathrm{X}$ UNT, $4 \mathrm{X}$ DL, $4 \mathrm{X}$ CPM, and $4 \mathrm{X}$ DLX CPM. Amendment incorporation into the soil increased soil pH slightly in the treated soil compared to the untreated one. This effect was in decreasing order based on mean values from 4 replicates): DL (7.5 \pm 0.14$)>\operatorname{CPM}(7.4 \pm 0.27)>\operatorname{DLX}$ CPM $(7.3 \pm 0.29)>\operatorname{UNT}(7.2 \pm 0.15)$. The organic matter added to the soil (i.e., CPM) resulted in reduction of EC $(856.75 \pm 122.00$ $\left.\mu \mathrm{S} . \mathrm{cm}^{-1}\right)$ compared to the DL $\left(1243.75 \pm 308.27 \mu{\mathrm{S} . \mathrm{cm}^{-1}}^{-1}\right.$, DLX CPM $\left(1278.75 \pm 152.18 \mu \mathrm{S} . \mathrm{cm}^{-}\right.$ $\left.{ }^{1}\right)$ and the UNT $\left(1172.75 \pm 214.72 \mu \mathrm{S} . \mathrm{cm}^{-1}\right)$. The soil amendments had no significant effect on the $\mathrm{pH}$ and $\mathrm{EC}$ of the four types of soil. In contrast, the addition of amendments significantly increased the DOC in the soil solution compared to the untreated soil $(p=0.019)$. This effect was in the following order: DLX CPM $\left(34.6 \pm 2.50 \mathrm{mg} . \mathrm{l}^{-1}\right)>\operatorname{DL}\left(29.2 \pm 6.14 \mathrm{mg} . \mathrm{l}^{-1}\right)>\mathrm{CPM}$ $\left(26.8 \pm 5.49 \mathrm{mg} . \mathrm{l}^{-1}\right)>\mathrm{UNT}\left(19.0 \pm 4.72 \mathrm{mg} . \mathrm{l}^{-1}\right)$. The amendments also had a significant effect on the total $\mathrm{Cr}$ concentration in the soils $(\mathrm{p}=0.000501)$. A good correlation was observed between soil $\mathrm{pH}$ and DOC $\left(\mathrm{R}^{2}=0.589\right)$, but poorer or lack of correlations were observed between the other variables used in our experiment.

\subsubsection{Concentration and Mineral mass of $\mathrm{Cr}$ in the bean leaves}

Table 4 shows that the measured $\mathrm{Cr}$ concentrations in the $\mathrm{BL}$ were less than the toxic concentrations measured in the tops of plants reported by Kitagishi and Yamane (1981), Gough et al. (1979) and Davis et al. (1978). The mean value of foliar $\mathrm{Cr}$ concentrations in the beans decreased from $1.438 \pm 1.23$ in the UNT soil to $0.733 \pm 0.08$ in the soil amended with CPM, to 
$0.588 \pm 0.17$ in the soil amended with DL and to $0.652 \pm 0.012$ in the soil amended with DLX CPM. However, the soil amendments (CPM, DL, DLX CPM) had no significant effects on the Cr concentrations in the BL $(\mathrm{p}=0.436)$ (Table 4).

Leaf Cr mineral mass $\left(\mathrm{g} \cdot \mathrm{ha}^{-1}\right)$ was computed with foliar Cr concentrations (mg.kg-1 DW) and foliar biomass (g DW per pot). We can clearly note in Table that soil amendments decreased the mineral mass of $\mathrm{Cr}$ in the BL compared to the UNT plants $(0.094 \pm 0.03 \mathrm{~g}$ per pot $)$. The lowest Cr mineral masses were observed for the DLX CPM plants $(0.067 \pm 0.01 \mathrm{~g}$ per pot $)$. This difference in the mineral masses is notably driven by the lower foliar $\mathrm{Cr}$ concentrations and dry weight in the DLX CPM plants. The DL and DLX CPM additions decreased the Cr mineral masses more than those for CPM and UNT. While amendments added to soil had a significant effect on the total $\mathrm{Cr}$ concentration $(\mathrm{p}=0.000501)$ in the four soils UNT $\left(15.52 \mathrm{mg} \cdot \mathrm{kg}^{-1}\right)$, $\mathrm{CPM}\left(14.81 \mathrm{mg} \cdot \mathrm{kg}^{-1}\right), \operatorname{DL}\left(17.05 \mathrm{mg} \cdot \mathrm{kg}^{-1}\right)$ and $\operatorname{DLX} \mathrm{CPM}\left(16.07 \mathrm{mg} \cdot \mathrm{kg}^{-1}\right)$, there was no significant effect of soil amendments on the concentration and the mineral masses of $\mathrm{Cr}$ in the plants.

Table 4. Dry weight (g), concentration $\left(\mathrm{mg} \mathrm{kg}^{-1}\right.$ ) and mineral mass of $\mathrm{Cr}$ (g per pot) measured in the BL.

$\begin{array}{lclc}\begin{array}{c}\text { Soil } \\ \text { amendments }\end{array} & \begin{array}{c}\text { Dry weight } \\ (\mathbf{g})\end{array} & \begin{array}{c}\text { Cr concentration in the plant } \\ \left(\mathbf{m g ~ k g ~}^{-\mathbf{1}}\right)\end{array} & \begin{array}{c}\text { Mineral mass }(\mathbf{g} \text { per } \\ \text { pot) }\end{array} \\ \text { UNT } & 0.087 \pm 0.04 & 1.438 \pm 1.23 & 0.094 \pm 0.03 \\ \text { CPM } & 0.112 \pm 0.02 & 0.733 \pm 0.08 & 0.083 \pm 0.01 \\ \text { DL } & 0.122 \pm 0.02 & 0.588 \pm 0.17 & 0.069 \pm 0.00 \\ \text { DLX CPM } & 0.103 \pm 0.00 & 0.652 \pm 0.012 & 0.067 \pm 0.01\end{array}$

\subsection{Neural network modeling results}


The ANN was trained with $3 \times 10^{4}$ epochs (number of training cycles). The training performance was assessed by the root mean square error (RMSE). At the end of the training phase, the RMSE convergence value was $1 \times 10^{-5}$. Table 5 shows the experimental and ANN predicted values of $\mathrm{Cr}$ concentration in the $\mathrm{BL}$ for the four soil groups (four different amendments) and their corresponding correlation coefficients.

Table 5. Comparison between averaged measured and ANN predicted values of $\mathrm{Cr}$ concentration in the bean leaves for the four soil groups. The determination coefficient $\mathrm{R}^{2}$ is based on the eight experimental samples kept for validation.

Soil (UNT) $\quad$ Soil (CPM) $\quad$ Soil (DL) $\quad$ Soil (DLX CPM)

\begin{tabular}{llllllll}
\hline Measured & NN & Measured & NN & Measured & NN & Measured & NN \\
3.29 & 3.285 & 0.762 & 0.764 & 0.519 & 0.519 & 0.524 & 0.523 \\
0.748 & 0.746 & 0.709 & 0.710 & 0.775 & 0.773 & 0.819 & 0.820 \\
0.601 & 0.600 & 0.392 & 0.391 & 0.892 & 0.890 & 0.805 & 0.804 \\
0.661 & 0.662 & 0.498 & 0.496 & 0.618 & 0.616 & 0.781 & 0.780 \\
$R^{2}=0.9998$ & $R^{2}=0.9986$ & $R^{2}=0.9989$ & $R^{2}=0.9991$
\end{tabular}

An average correlation coefficient of 0.9998 between the measured and ANN predicted values as found. This indicates that the ANN model was able to predict the Cr concentration in the BL rapidly and accurately. In order to investigate the effects of the soil amendments, soil $\mathrm{pH}$, soil EC and DOC inputs on the Cr concentration in the BL, a parametric study of the ANN output with respect to the inputs was performed for each soil treatment with the trained ANN. For each input factor, four values in the interval between the minimum and maximum values of each input were applied here to capture the non-linear response (Table 6). Full factorial design generated $256(4 \times 4 \times 4 \times 4)$ combinations to study the effect of each input on the Cr response. The computation time was about 2 seconds. 
Table 6. Selected four inputs for the ANN prediction. Full factorial combinations generate $256(4 \times 4 \times 4 \times 4)$ data to investigate their effects on soil response.

\begin{tabular}{|c|c|c|c|c|c|c|}
\hline Inputs & Min & Max & Level & 1 Level & Level 3 & Level 4 \\
\hline il treatment & $\# 1$ & $\# 4$ & UNT & $\mathrm{CPM}$ & $\mathrm{DL}$ & DLX CPM \\
\hline & 6.98 & 7.6 & 7.0 & 7.2 & 7.4 & 7.6 \\
\hline$(\mu \mathrm{S} \mathrm{cm})^{-1}$ & 754 & 1654 & 800 & 1100 & 1400 & 1600 \\
\hline $\mathrm{DC}\left(\mathrm{mg} \mathrm{l}^{-1}\right.$ & 14.33 & 34.260 & 14 & 20 & 28 & 34 \\
\hline
\end{tabular}

To explore the relationships between the inputs and the output, several response surfaces (RS) were plotted consisting of 3D graphical representation of a response between two independent variables (inputs) and the output. The 3D RS plots provide insight into the behavior of the system and enable investigation of the parametric $\mathrm{Cr}$ concentration results versus the levels of the effecting factors predicted by the ANN model. Figure 3 shows the coupled effects of the $\mathrm{pH}$ and $\mathrm{EC}$ on the $\mathrm{Cr}$ concentration in $\mathrm{BL}$ for two different values of DOC (14 and $\left.34 \mathrm{mg} \cdot \mathrm{l}^{-1}\right)$. 


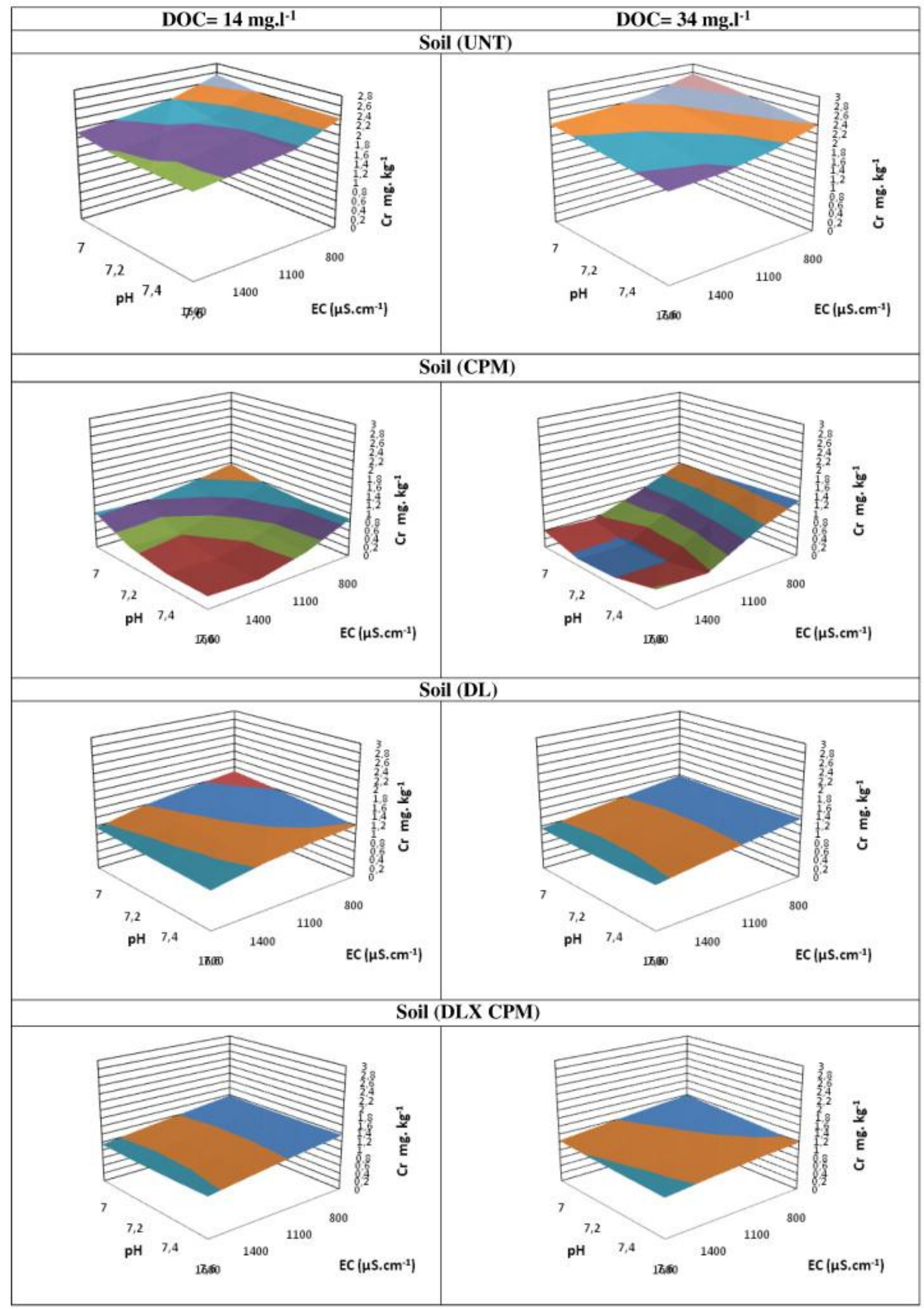

Fig. 3. Chromium concentration in $\mathrm{BL}$ in $\mathrm{mg} \mathrm{kg}^{-1}$ : effects of soil $\mathrm{pH}$ and $\mathrm{EC}$ for two different limit values of DOC. 
The predicated $\mathrm{Cr}$ concentration depends strongly on the soil factors and the type of amendments. It can be seen in the left-hand column of Figure 3 that soil amendments (CPM, DL and DLX CPM) and other factors such as $\mathrm{pH}, \mathrm{EC}$ and low DOC (DOC=14 mg..$^{-1}$ ) decreased the $\mathrm{Cr}$ concentration in the BL to $1,1.2$ and $1.4 \mathrm{mg} \cdot \mathrm{kg}^{-1}$, respectively, compared to the untreated soil which presents a reference $\mathrm{Cr}$ concentration of about $2.4 \mathrm{mg} \cdot \mathrm{kg}^{-1}$. The same effect of soil amendments can be observed when the DOC value increased to $34 \mathrm{mg} . \mathrm{l}^{-1}$ (Fig. 3 right-hand column). If we compare the right and left columns of Figure 3, we can see that the increase in DOC concentration from 14 to $34 \mathrm{mg} \cdot \mathrm{l}^{-1}$ in the soil slightly increased the availability of $\mathrm{Cr}$ to plants in the treated (CPM, DL, DLX CPM) and UNT soils by $0.3,0.2,0.2,0.4$ mg.kg ${ }^{1}$,respectively.

Barcelona and Holm (1991), Pantsar-Kallio et al. (2001) and Seaman et al. (2001) reported that oxidation and reduction reactions are important in the fate, transport, and toxicity of $\mathrm{Cr}$ in the soil. These reactions are governed by many factors including organic matter, $\mathrm{pH}$, aeration, soil moisture content, wetting and drying, microbial activity, the content in clay minerals and availability of electron donors and acceptors. Moreover, the amendments added to the soil have the capacity to change the $\mathrm{Cr}$ from $\mathrm{Cr}(\mathrm{VI})$, which has a high mobility and toxicity and facilitates leaching, to $\mathrm{Cr}$ (III), which is relatively insoluble and resistant to leaching (James et al., 1997). Fendorf (1995) also reported that the reduction of $\mathrm{Cr}$ in soils is accelerated by the presence of organic matter and divalent iron. If $\mathrm{Cr}$ in the soil is converted to trivalent oxide or co-precipitated with Fe hydrous oxide or organic matter, it is likely to remain stable for a long time. Our results agree with those of Hsu et al. (2000), who reported that the high affinity of metals for CPM had two-sided consequences. The first is that in the presence of DOC the mobility of trace elements increases by forming complexes with the humic acid and fulvic acid, leading to the high mobility and availability of metals to plants. Secondly, non soluble high 
molecular weight organic acids can retain significant concentrations of trace metals in soil upon soil acidification, thus decreasing their mobility (Chirenje et al., 1999).

The concurrent effect of the three studied factors can be observed clearly in the soil treated with CPM (Fig. 3- right-hand column), where it can be seen that the increase in the DOC value (34 mg. ${ }^{-1}$ ) led to an increase in the Cr availability to the plant from 1.2-1.4 mg. $\mathrm{kg}^{-1}$ in the case of DOC $=34 \mathrm{mg} . \mathrm{l}^{-1}$ compared to soil treated with CPM containing less DOC $\left(14 \mathrm{mg} . \mathrm{l}^{-}\right.$ $\left.{ }^{1}\right)$ where it decreased from 1.2 to $0.8 \mathrm{mg} \cdot \mathrm{kg}^{-1}$. The increase in $\mathrm{pH}$ leads to a slight decrease in $\mathrm{Cr}$ concentration in plants, whereas the decrease in EC leads to a strong increase in $\mathrm{Cr}$ concentration in the $\mathrm{BL}$ from 0.2 at $\mathrm{EC}=1100 \mathrm{mg} \cdot \mathrm{kg}^{-1}$ to 1.3 at $\mathrm{EC}=800 \mathrm{mg} \cdot \mathrm{kg}^{-1}$ in the case of DOC $=34 \mathrm{mg} \cdot \mathrm{l}^{-1}$. This result can be explained by the fact that in the case of anions $(\mathrm{Cr}(\mathrm{VI}))$, the decrease in $\mathrm{pH}$ promotes the release of $\mathrm{HO}$-ions. This then leads to a decrease in competition between anions and HO-ions, which then accelerates the formation of new phases. Thus, the solubility of $\mathrm{Cr}$ anions decreases when $\mathrm{pH}$ decreases. Dzombak and Morel (1990) reported that when soil $\mathrm{pH}$ increases, the mobility of metals decreases, thereby decreasing the uptake of $\mathrm{Cr}$ by living species as in the case of soil treated with DL, CPM at DOC $=14 \mathrm{mg} \cdot \mathrm{l}^{-1}$. Another important factor that has a major effect on the bioavailability of $\mathrm{Cr}$ is EC. Increases in chloride, sulfate, carbonate, bicarbonate, nitrate and phosphate concentrations in solution lead to the formation of metallic salts, which increase the EC of the soil solution. An increase in salinity is associated with an increase in the concentration of major elements ( $\mathrm{Na}, \mathrm{K}, \mathrm{Ca}, \mathrm{Mg}$ ), which compete with trace metals for sorption sites (Tam and Wong, 1999). This is different from our results where we found that the increase in DOC and $\mathrm{pH}$ and decrease in EC lead to an increase in $\mathrm{Cr}$ concentration in plants.

The predicted findings suggest that due to the large variation of $\mathrm{Cr}$ concentration in the BL with different treatments, the best amendment for reducing soil $\mathrm{Cr}$ toxicity is the (CPM) treatment. This reduced $\mathrm{Cr}$ concentration from $2.4 \mathrm{mg} \cdot \mathrm{kg}^{-1}$ in the untreated soil to $1 \mathrm{mg} \cdot \mathrm{kg}^{-1}$ 
(case of DOC=14 mg. $\mathrm{l}^{-1}$ ) and from $2.8 \mathrm{mg} \cdot \mathrm{kg}^{-1}$ in the untreated soil to $1.2 \mathrm{mg} \cdot \mathrm{kg}^{-1}$ (case of DOC $=34 \mathrm{mg} \cdot \mathrm{l}^{-1}$ ). These two DOC values result in non-linear $\mathrm{Cr}$ variation versus $\mathrm{pH}$ and $\mathrm{EC}$. However, the DL and DLX CPM treatments generated intermediate Cr concentration levels but with a more stable (linear) variation compared to that of the CPM treatment.

When all the results are considered, it can be seen that the $\mathrm{Cr}$ tends to evolve from nonlinear responses for UNT and CPM soils to linear responses for DL and DLX CPM soils.

UNT soil generated the highest non-linear variation in $\mathrm{Cr}$ concentration, suggesting that the results are sensitive to $\mathrm{pH}$ and EC. Such a variation is reduced, however, with the addition of CPM and DL or with a combined treatment (DLX CPM). We found that among the investigated factors, $\mathrm{pH}$ and $\mathrm{DOC}$ are the most important parameters affecting the $\mathrm{Cr}$ concentration in BL.

However, there are only a limited number of published studies available for describing the techniques of stabilization of $\mathrm{Cr}$ in the soil. Because of the low reactivity of its common species in soils, even if $\mathrm{Cr}$ is added to soil in the mobile form $\mathrm{Cr}(\mathrm{VI})$, it can be converted to its stable form $\mathrm{Cr}(\mathrm{III})$. Jop et al. (1987) reported that the dominant species of $\mathrm{Cr}(\mathrm{V} 1)$ at $\mathrm{pH}>6.5$ is chromium oxide (the case of our soil). As $\mathrm{Cr}(\mathrm{VI})$ species are negatively charged, they do not complex with anionic particulate matter and are more bioavailable. In our experience, we have noted that the addition of both organic and inorganic amendments to the soil can decreased the bioavailability of $\mathrm{Cr}$ with reference to untreated soil.

\subsection{Comparison of MLR and ANN performance}

Four MLR experiments were performed, one each of the four soil training data pertaining to every amendment, to quantify the relationships between $\mathrm{Cr}$ concentration in $\mathrm{BL}$ 
and the soil factors $(\mathrm{pH}, \mathrm{EC}$ and DOC). The software used for the purpose of statistical analyses was Statistica 10. These four MLR equations are:

\begin{tabular}{|c|l|}
\hline Amendment & MLR equations per amendment \\
\hline UNT & $Y_{B L}=2.255+0.0623 \times x_{p H}-6.44 e^{-4} \times x_{E C}+0.00128 \times x_{D O C}$ \\
\hline DL & $Y_{B L}=2.987-0.113 \times x_{p H}-1.26 e^{-3} \times x_{E C}+0.00097 \times x_{D O C}$ \\
\hline CPM & $Y_{B L}=1.851+0.0124 \times x_{p H}-6.67 e^{-4} \times x_{E C}+0.00115 \times x_{D O C}$ \\
\hline DLX CPM & $Y_{B L}=1.986+0.0118 \times x_{p H}-6.61 e^{-4} \times x_{E C}+0.00101 \times x_{D O C}$ \\
\hline
\end{tabular}

where $x_{p H}, x_{E C}$ and $x_{D O C}$ denote, respectively, values of $\mathrm{pH}, \mathrm{EC}$ and DOC.

After determining of these equations, comparison between predictive results of the ANN and MLR models was performed for the training and test data sets. The obtained coefficients of correlations among the results (Table 7). This indicates that the results of ANN model are better than that of MLR models for all amendment cases. Our finding agrees well with those of van der Zee and van Riemsdijk (1987), Andersen and Christensen (1988), Streck and Richter (1997), Römkens and Salomons (1998), Tiktak et al. (1998), Schaap and Lei (1998), Elzinga et al. (1999), Sarmadian and Taghizadeh Mehrjardi (2008).

Table 7. Correlation coefficients obtained by ANN and MLR methods.

\begin{tabular}{|c|c|c|c|c|c|c|c|c|}
\hline \multirow{2}{*}{ Method } & \multicolumn{2}{|c|}{ UNT } & \multicolumn{2}{|c|}{ CPM } & \multicolumn{2}{|c|}{ DL } & \multicolumn{2}{|c|}{ DLX CPM } \\
\hline & $\begin{array}{c}\text { Trainin } \\
\text { g data }\end{array}$ & $\begin{array}{c}\text { Trainin } \\
\text { g data }\end{array}$ & $\begin{array}{c}\text { Trainin } \\
\text { g data }\end{array}$ & $\begin{array}{c}\text { Trainin } \\
\text { g data }\end{array}$ & $\begin{array}{c}\text { Trainin } \\
\text { g data }\end{array}$ & $\begin{array}{c}\text { Trainin } \\
\text { g data }\end{array}$ & $\begin{array}{c}\text { Trainin } \\
\text { g data }\end{array}$ & $\begin{array}{c}\text { Trainin } \\
\text { g data }\end{array}$ \\
\hline $\begin{array}{l}\text { Neural } \\
\text { network }\end{array}$ & 0.999 & 0.998 & 0.998 & 0.996 & 0.998 & 0.997 & 0.999 & 0.995 \\
\hline $\begin{array}{l}\text { Linear } \\
\text { regressio } \\
n\end{array}$ & 0.876 & 0.695 & 0.792 & 0.702 & 0.765 & 0.637 & 0.882 & 0.802 \\
\hline
\end{tabular}




\section{Conclusion}

Reducing the concentration of $\mathrm{Cr}$ in contaminated soils can be performed by adding soil amendments. These amendments reduce $\mathrm{Cr}$ mobility by promoting the formation of insoluble precipitates or by enhancing the soil's capacity to bind $\mathrm{Cr}$ to the soil. The latter can be achieved directly through the addition of adsorbent materials or indirectly by adjusting the soil's $\mathrm{pH}-\mathrm{EC}$ combination to provoke $\mathrm{Cr}$ absorption onto the soil. In this preliminary study, three factors were retained ( $\mathrm{pH}, \mathrm{EC}$ and DOC) in combination with four soil amendments (UNT, CPM, DL and DLX CPM). The present study confirmed that organic matter (CPM) is one of the best soil amendments, as it reduced the concentrations of $\mathrm{Cr}$ in the BL more than the other amendments. The interactions of the soil factors in the form of response surfaces were analyzed and compared to existing published results. This methodology could be effectively used to study the importance of individual, cumulative and interactive effects of the selected soil inputs in $\mathrm{Cr}$ concentration in bean leaves. The predictive ANN models used to evaluate the $\mathrm{Cr}$ concentration corresponded well with the experimental results reported in the literature. The ANN models developed here showed that a plausible innovative low-cost strategy for in situ remediation of $\mathrm{Cr}$ contaminated soils using organic and inorganic amendments, modified vegetation, or a combination of the two approaches. It should be noted that the ANN approach proposed here does not take into account all the possible factors that may influence soil toxicity. The primary aim was to illustrate the potential of the ANN method in its ability for rapid and accurate prediction of soil toxicity. The ANN model can be extended by including additional factors and their combinations to capture complex Cr behavior.

Overall, the ANN modeling outperforms MLR modeling. The effort required to calibrate the ANN and MLR models were similar, and both require about the same amount of time and processing resources. Despite their good performance, ANNs suffer from a number of 
limitations. First, they are not able to explain the physical relationships between the inputoutput data. Secondly, there are no general guidelines for the design of ANN architecture for a given problem. There is a need for more research to develop such guidelines to enable the extensive application of ANNs for non-specialists. Nevertheless, ANNs have a number of significant benefits that make them a powerful, rapid and practical tool for solving many soil engineering problems. The implementation of ANN modeling for the robust and reliable prediction of metal concentration in plants using additional soil data such as soil particle size and moisture levels in a practical sensor system appears very promising. Future significant work is required to achieve this goal. The results of ANN testing (prediction) allow for the investigation of the soil factors' interactions. This methodology could therefore be effectively used to study the importance of individual, cumulative and interactive effects of the soil parameters. Moreover, the ANN method can be used in conjunction with mechanistic models at the research level as a method to determine the most important parameters in a design that could then be used to formulate a mechanistic model and to determine where future research efforts should be directed.

\section{Acknowledgements}

Our work was financially supported by ADEME (Projects PhytoDEMO and CWdemo), Department of Brownfields and Polluted Sites, Angers, France, the Aquitaine Region Council (Project Phytorem), Bordeaux, France, and the European Commission under the Seventh Framework Programme for Research (FP7-KBBE-266124, GREENLAND). The authors would like to thank the anonymous reviewers for their valuable efforts, comments and suggestions to improve the manuscript. 


\section{References}

Adriano, D.C., 2001. Trace elements in terrestrial environments; Biochemistry, bioavailability and risks of metals. Springer-Verlag, New York.

AFNOR NF X 31-147 : (Qualité des sols) : Sols, sédiments - Mise en solution totale par attaque acide.

Anagu, I., Ingwersen, J., Utermann, J., Streck, T., 2009. Estimation of heavy metal sorption in German soils using artificial neural networks. Geoderma 152, 104-112.

Andersen, P.R., Christensen, T.H., 1988. Distribution coefficients of $\mathrm{Cd}, \mathrm{Co}, \mathrm{Ni}$ and $\mathrm{Zn}$ in soils. Journal of soil science 39, 15-22.

Baize, D., 1997. Un Point sur Les Teneurs Totales des Eléments Traces Métalliques dans les Sols, INRA Editions, Paris, France, pp 408.

Baize, D., Tercé, M., 2002. Les Éléments Traces Métalliques dans les Sols - Approches Fonctionnelles et Spatiales, INRA Éditions, Paris, France. pp 570.

Barcelona, M.J., Holm, T.R., 1991. Oxidation-reduction capacities of aquifer solids. Environmental science and technology 25, 1565-1571.

Behrens, T., Förster, H., Scholten, T., Steinrüken, U., Spies, E., Goldschmitt, M., 2005. Digital soil mapping using artificial neural networks. Journal of plant nutrition and soil science $168,21-33$

Bes, C., Mench, M., 2008. Remediation of copper-contaminated topsoils from a wood treatment facility using in situ stabilisation. Environmental Pollution 156, 1128-1138.

Bes, C., 2008. Phytoremédiation des sols d'un site de traitement du bois contaminé par le cuivre. Ph.D. Dissertation, Université de Bordeaux1, Talence, France. 
Bes, C.M., Mench, M., Aulen, M., Gaste, H., Taberly, J., 2010.Spatial variation of plant communities and shoot $\mathrm{Cu}$ concentrations of plant species at a timber treatment site. Plant Soil 330, 267-80.

Buszewski, B., Kowalkowski, T., 2006. A new model of heavy metal transport in the soil using non-linear artificial neural networks. Journal of environmental engineering science 23 (4), 589-595.

Chirenje, T., Ma, L.Q., 1999. Effects of acidification on metal mobility in a papermill-ash amended soil. Journal of Environmental Quality 28, 760-767.

Ciesielski, H., Sterckeman, T., 1997. Determination of exchange capacity and exchangeable cations in soils by means of cobalt hexamine trichloride. Effects of experimental conditions, Agronomie 17, 1-7.

Ciesielski, H., Proix, N., Sterckeman, T., 1997. Détermination des incertitudes liées à une méthode de mise en solution des sols et des sédiments par étude inter laboratoire. Analusis 25, 6, 188-192.

Davis, R.D., Beckett, P.H.T., Wollan, E., 1978. Critical levels of twenty potentially toxic elements in young spring barley. Plant Soil 49, 395-408.

Davies, B.E., 1992. Inter-relationships between soil properties and the uptake of cadmium, copper, lead and zinc from contaminated soils by radish (Raphanus sativus L.). Water, Air, Soil Pollution 63,331-342.

Du Laing, G., De Vos, Vandecasteele, B., Lesage, E., Tack, F.M.G., Verloo, M.G., 2008. Effect of salinity on heavy metal mobility and availability in intertidal sediments of the Scheldt estuary. Estuarine coastal and shelf science 77, 589-602.

Du Laing, G., Van de Moortel, A., Moors, W., De Grauwe, P., Meers, E., Tack, F., Verloo, M., 2009. Factors affecting metal concentrations in reed plants (Phragmites australis) of intertidal marshes in the Scheldt estuary. Ecological engineering 35, 310-318. 
Dzombak, D.A., Morel, F.M.M., 1990. Surface Complexation Modeling - Hydrous Ferric Oxide. John Wiley \& Sons (A Wiley-Interscience Publication), pp 393.

Elzinga, E.J., Van Grinsven, J.J.M., Swartjes, F.A., 1999. General purpose Freundlich isotherms for cadmium, copper and zinc in soils. European Journal of Soil Science 50, 139-149.

Fendorf, S., 1995. Surface reactions of chromium in soils and waters. Geoderma 67, 55-71.

Fischer, K. Removal of heavy metals from soil components and soil by natural chelating agents. 2000, Part 1: Displacement from clay minerals and peat by L-cysteine and Lpenicillamine. Water, Air, Soil Pollution 137, 267.

Förstner, U., 1985. Chemicals forms and reactivities of metals in sediments in "chemical methods for assessing bio-available metals in sludges and soil", Leschber R., Davis R.D., L'Hermite P., CEC, Elsevier Applied Science publishers, 1-30.

Gandhimathi, A., Meenambal, T., 2012. Analysis of Heavy Metal for Soil in Coimbatore by using ANN Model. European Journal of Scientific Research 68, (4), 462-474.

Gough, L.P., Shacklette, H.T., Case, A.A., 1979, Element Concentrations Toxic to Plants, Animals, and Man, US Geological Survey Bulletin 1466, 80.

Hambli, R., 2009. Statistical damage analysis of extrusion processes using finite element method and neural networks simulation. Finite Elements in Analysis and Design -45- 10, 640-649.

Hambli, R., Chamekh, A., Bel Hadj Salah, H., 2006. Real-time deformation of structure using finite element and neural networks in virtual reality applications, Finite Elements in Analysis and Design 42, (11), 985-991.

Hatje, V., Payne, T.E., Hill, D.M., McOrist, G., Birch, G.F., Szymczak, R., 2003. Kinetics of trace element uptake and release by particles in estuarine waters: effects of $\mathrm{pH}$, salinity, and particle loading. Environment International 29, 619-629. 
Haykin, S., 2009. Neural Networks and learning machine (3rd Edition), Pearson, 936 p.

Heijerick, D.G., Janssen, C.R., De Coen, W.M., 2003. The combined effects of hardness, pH and dissolved organic carbon on the chronic toxicity of $\mathrm{Zn}$ to D. magna: development of a surface response model. Archives of Environmental Contamination and Toxicology 44, $210-217$.

Hsu. J.H,. Lo. S.L., 2000. Characterisation and extractability of copper. manganese. and zinc in swine manure composts. Journal of Environmental industry. Environment pollution 101, $43-48$

Jackson, M.L., 1967. Soil Chemical Analysis. Prentice Hall of India Pvt. Ltd., New Delhi, pp 49.

Jackson, B.P., Miller, W.P., 2000. Soil solution chemistry of a fly ash-. poultry litter-. and sewage sludge-amended soil. Journal of Environmental Quality 29 (2), 430-436.

James, B.R., Petura, J.C., Vitale, R.J., Mussoline, G.R., 1997. Oxidation-reduction chemistry of chromium: Relevance to the regulation and remediation of chromate contaminant soils. Journal of soil contamination $6,569-580$.

Jenkins, W.M., 1997. An introduction to neural computing for the structural engineer. Journal of structural engineering $753,38-41$.

Jop, K.M., Parkerton, T.F., Rodgers, J.H.Jr., Dickson, K.L., 1987. Comparative toxicity and speciation of two hexavelant chromium salts in acute toxicity tests. Journal of environmental toxicology and chemistry 6, 697-703.

Kabata-Pendias, H., Pendias., 2000. Trace Elements in Soils and Plants. CRC Press, Boca Raton, Florida, USA.

Kafadar, K., 1994. Choosing among two-dimensional smoothers in practice. Computational Statistics and Data Analysis 18, 419-439. 
Katz, S.A., Salem, H., 1994. The biological and environmental chemistry of chromium. VCH Publishers, Inc., New York.

Kerndorff, H., Schnitzer, M., 1980. Sorption of metals on humic acids. Geochimica et Cosmochimica Acta 44,1701.

Kitagishi, K., Yamane, I (Eds.)., 1981. Heavy Metal Pollution in Soils of Japan, Japan Scientific Societies Press, Tokyo, 107-124.

Kolbas, A., Mench, M., Herzig, R., Nehnevajova, E., Bes, C.M., 2011. Copper phytoextraction in tandem with oilseed production using commercial cultivars and mutant lines of sunflower. International Journal of Phytoremediation 13 Suppl 1, 55-76.

Kotas, J., Stasicka, Z., 2000. Commentary: chromium occurrence in the environment and methods of its speciation. Environmental Pollution, 107, 263- 83.

Kowalski, Z. J., 1994. Treatment of chromic tannery wastes. J Hazard Mater 37: 137-144.

McBratney, A.B., Mendoca Santos, M.L., Minasny, B., 2003. On digital soil mapping. Geoderma 117, 3-52.

McLean, J.E., Bledsoe, B.E., 1992. Behaviour of metals in soils. Ground water issue, USEPA, Washington, DC. EPA/540/S-92/018.

Mench, M., Bes, C., 2009. Assessment of ecotoxicity of topsoils from a wood treatment site. Pedosphere 19,143-155.

Minasny, B., McBratney, A.B., 2002. The neuro-m methods for fitting neural network parametric pedotransfer functions. Soil Science Society of America Journal 66, 352-361.

Minasny, B., Hopmans, J.W., Harter, T., Eching, S.O., Tuli, A., Denton, M.A., 2004. Neural networks prediction of soil hydraulic functions for alluvial soils using multistep outflow data. Soil Science Society of America Journal 68, 417-429.

Murti, K., Viswanathan, C.R., Puspa., 1989. Toxic Metals in the Indian environment and its human health implication. Tata Mc Graw Hill Publication, 131-148. 
Pantsar-Kallio, M., Reinikainen, S.P., Oksanen, M., 2001. Interactions of soil components and their effects on speciation of chromium in soils. Analytica Chimica Acta 439, 9-17.

Rafiq, M.Y., Bugmann G., Easterbrook, D. J., 2001. Neural network design for engineering applications. Computers \& Structures, 79, (17), 1541-1552.

Reinds, G.J., Bril, J., De Vries, W., Groenenberg, J.E., Breeuwsma, A., 1995. Critical loads and excess loads of cadmium, copper and lead for European forest soils. DLO Winand Staring Centre Report 96, Wageningen, the Netherlands.

Ruggiero, M.A., 1997. Cybernetic Trading Strategies, John Wiley \&Sons, 336 pages ISBN 0471149209.

Römkens, P.F.A.M., Salomons, W., 1998. Cd, Cu and Zn solubility in arable and forest soils: consequences of land use changes for metal mobility and risk assessment. Soil Science $163,859-871$.

Sarmadian, F., Taghizadeh Mehrjardi, R., 2008. Modeling of Some Soil Properties Using Artificial Neural Network and Multivariate Regression in Gorgan Province, North of Iran, Global Journal of Environmental Research 2 (1), 30-35.

Sauerbeck, D. R., Hein, A., 1991. The nickel uptake from different soils and its prediction by chemical extractions. Water Air Soil Pollution 57-58, 861-871.

Schaap, M.G., Leij, F.J., 1998. Using neural networks to predict soil water retention and soil hydraulic conductivity. Soil and Tillage Research 47, 37-42.

Schaap, M.G., Leij, F.J., van Genuchten, M.T., 1998. Neural networks analysis for hierarchical prediction of soil hydraulic properties. Soil Science Society of America Journal 62, $847-855$.

Schug, B., Düring, R.A., Gäth, S., 2000. Improved cadmium sorption isotherms by the determination of initial contents using the radioisotope $109 \mathrm{Cd}$. Journal of plant nutrition and soil science 163, 197-202. 
Seaman, J.C., Arey, J.S., Bertsch, P.M., 2001. Immobilization of nickel and other metals in contaminated sediments by hydroxyapatite addition. Journal of Environmental Quality 30 (2), $460-469$.

Smith. S. R., 1994. Effect of soil pH on availability to crops of metals in sewage sludge-treated soils. 1. Nickel, copper and zinc uptake and toxicity to ryegrass. Journal of environmental pollution $85,321-327$

Soon, Y. K., Bates, T. E., 1982. Chemical pools of $\mathrm{Cd}$, Ni and $\mathrm{Zn}$ in polluted soils and some preliminary indications of their availability to plants. Soil Science 33, 477-88.

Streck, T., Richter, J., 1997. Heavy metal displacement in a sandy soil at the field scale: I. Measurements and parameterization of sorption. J. Environ. Qual 26, 49-56.

Tam, NFY., Wong, YS., 1999. Mangrove soils in removing pollutants from municipal wastewater of different salinities. Journal of environmental quality $28,556-564$.

Tiktak, A., Alkemade, J.R.M., Van Grinsven, J.J.M., Makaske, G.B., 1998. Modeling cadmium accumulation at a regional scale in the Netherlands. Nutr, Cycl. Agroecosys. 50, 209-222. Van der Zee, S.E.A.T.M., van Riemsdijk,W.H., 1987. Transport of reactive solute in spatially variable soil systems. Journal of water resource research 23, 2059-2069.

Velleman, P. F., 1980. Definition and comparison of robust nonlinear data smoothing algorithms', Journal of the American Statistical Association, 75, 609-615.

Vogeler, I., Green, S.R.., Clothier, B.E., Kirkham, M.B., Robinson, B.H., 2001. Contaminant transport in the root zone. in Trace Elements in Soil: Bioavailability, Flux and Transfer. I.K. Iskandar and M.B. Kirkham, Eds. Lewis Publishers. Boca Raton, FL, chap. 9.

Weng, L.P., Temminghoff, E.J., Lofts, S., Tipping, E., Van Riemsdijk, W.H., 2002. Complexation with dissolved organic matter and solubility control of heavy metals in a sandy soil. Journal of environmental science and technology. 36, 4804-4810. 
Wetterhahn, K. E., Hamilton, J.W., 1989. Molecular basis of hexavalent chromium carcinogenicity: Effect on gene expression. Science of The Total Environment, 86, (1-2), 113-129. 


\section{$\underline{\text { Figures }}$}

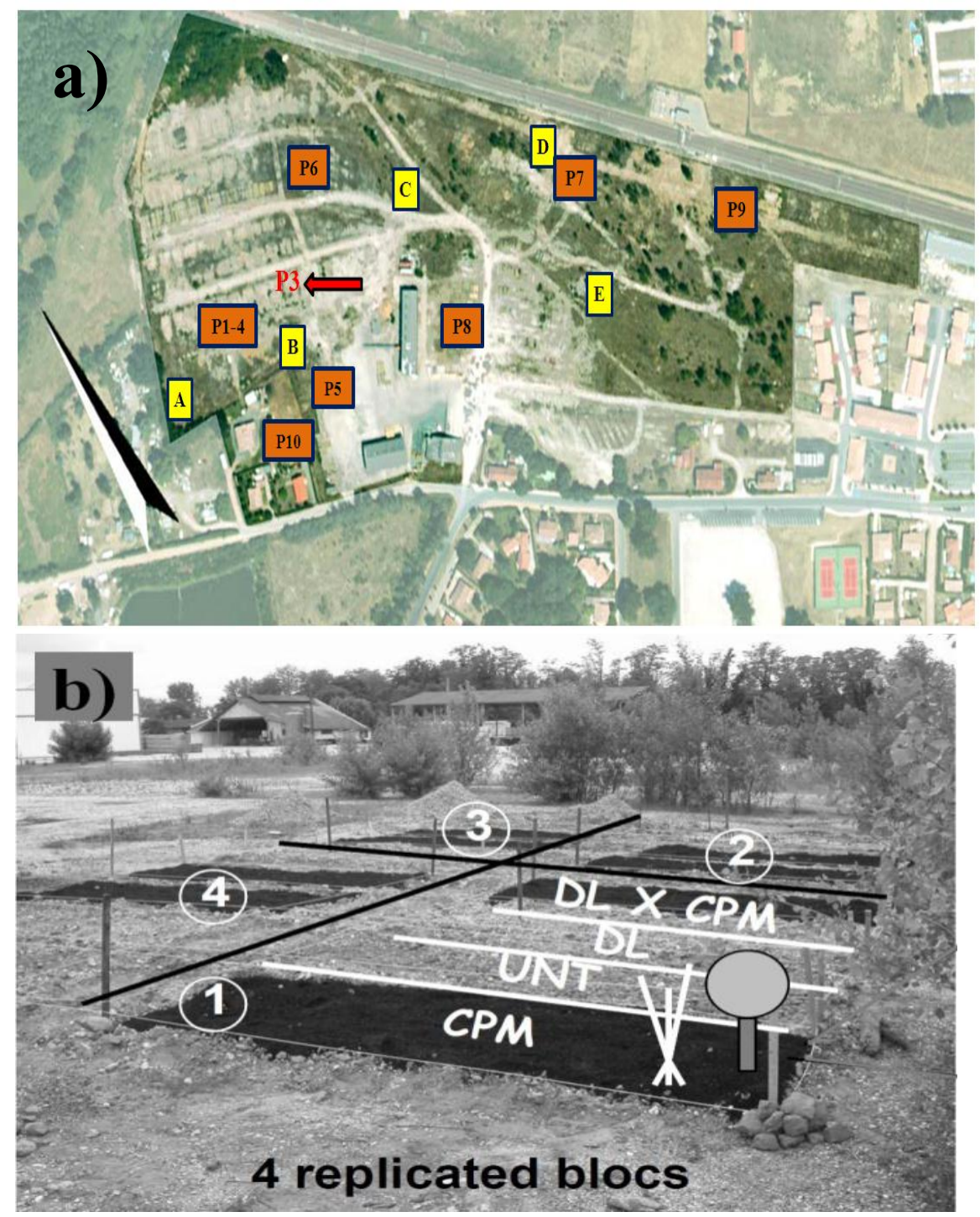

Figure1. a) Location of studied sites from A to E. The arrows indicate the studied site P3 (adapted from Mench and Bes, 2009)- b) The two plots of soil with the different types of amendment (adapted from Bes, 2008). 


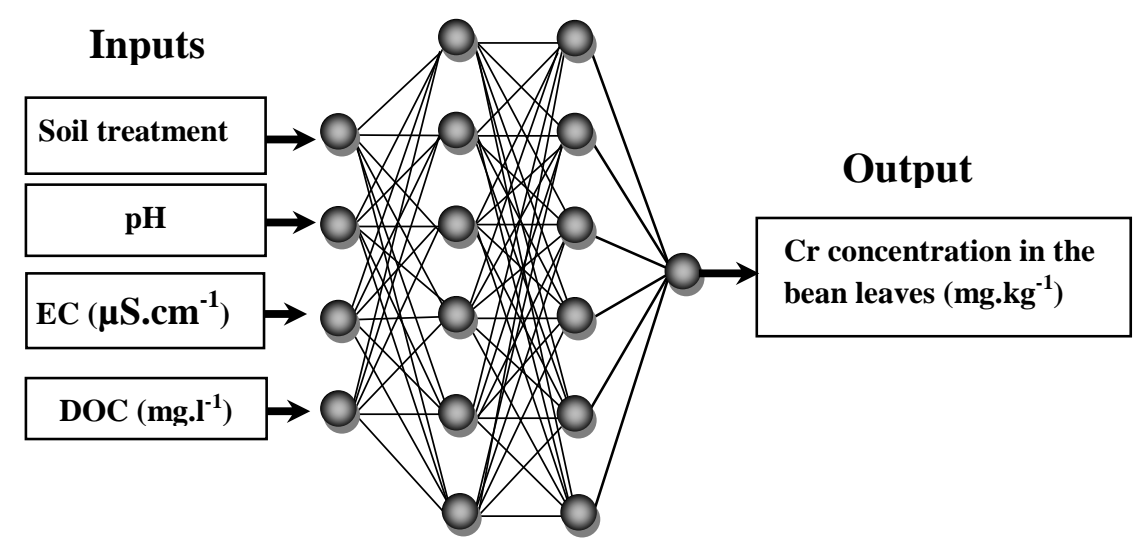

Figure 2. Neural network architecture composed of four input layers, two hidden layers and one output layer. 


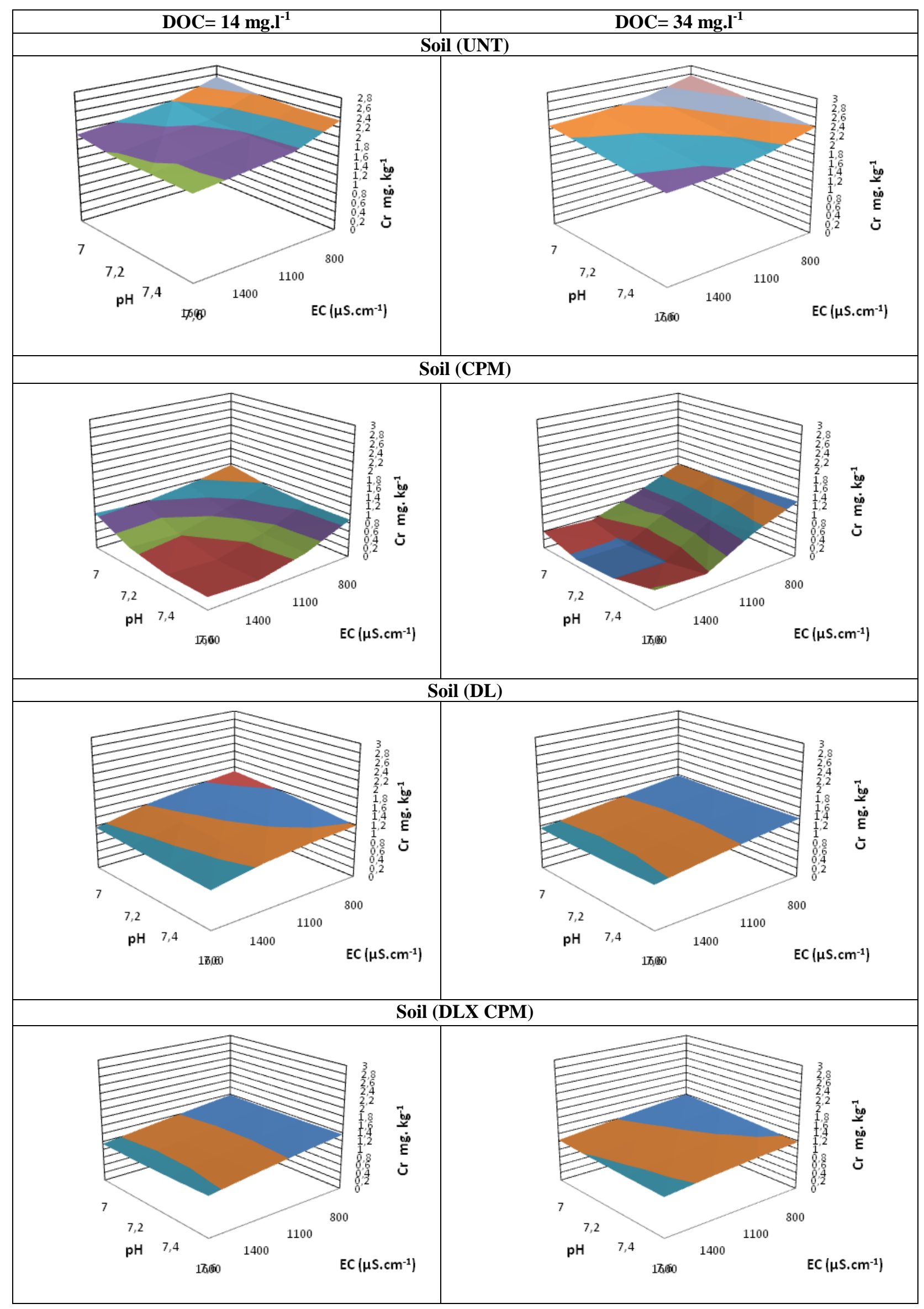


Figure 3. Chromium concentration in $\mathrm{BL}$ in $\mathrm{mg} \cdot \mathrm{kg}^{-1}$ : effects of soil $\mathrm{pH}$ and $\mathrm{EC}$ for two different limit values of DOC. 


\section{The tables}

Table 1. Main characteristics of site P3 (0-0.25 m soil layer).

\begin{tabular}{|c|c|c|}
\hline Parameters & Site P3 & $\begin{array}{l}\text { Background values in } \\
\text { French sandy soils }\end{array}$ \\
\hline Sand $\%$ & $83.5 \pm 1.1$ & \\
\hline Silt $\%$ & $11.5 \pm 0.9$ & \\
\hline Clay \% & $3.8 \pm 1.2$ & \\
\hline $\mathrm{C} / \mathrm{N}$ & 17.2 & \\
\hline OM (g.kg-1 $)$ & 15.9 & \\
\hline CEC $\left(\mathrm{cmol}^{+} . \mathrm{kg}^{-1}\right)$ & 3.49 & \\
\hline Organic C (g.kg $\left.{ }^{-1}\right)$ & 9.19 & \\
\hline total $\mathbf{N}\left(\mathrm{g} \cdot \mathrm{kg}^{-1}\right)$ & 0.534 & \\
\hline pH & $7.0 \pm 0.23$ & \\
\hline As $\left(\mathbf{m g . k g}{ }^{-1}\right)$ & 9.8 & $1.0-25^{\mathrm{b}}$ \\
\hline Co $\left(\right.$ mg.kg $\left.{ }^{-1}\right)$ & 2 & $1.4-6.8$ \\
\hline $\mathrm{Cu}\left(\mathrm{mg} \cdot \mathrm{kg}^{-1}\right)$ & $674 \pm 126$ & $3.2-4.8$ \\
\hline $\mathrm{Cr}\left(\mathbf{m g . k g}{ }^{-1}\right)$ & 23 & $14.1-40.2$ \\
\hline $\operatorname{Mn}\left(\mathbf{m g} \cdot \mathrm{kg}^{-1}\right)$ & 181 & $72-376$ \\
\hline Ni (mg.kg $\left.{ }^{-1}\right)$ & 5 & $4.2-14.5$ \\
\hline Zn (mg.kg-1) & 46 & $17-48$ \\
\hline
\end{tabular}

${ }^{a}$ median and high vibrissae values except for As (Baize., 1997; Baize and Tercé, 2002). ${ }^{\mathrm{b}}$ common As mean values for all French soil types (Baize and Tercé, 2002). 
Table 2. The experimental values ( $\mathrm{pH}, \mathrm{EC}, \mathrm{DOC}$ and $\mathrm{Cr}$ ). Four replications were performed for each measurement generating 64 testing results $(4$ soils $\times 4$ amendments $\times 4$ replicates) allowing for the determination of the mean values, standard deviations (SD) and coefficient of variations $(\mathrm{COV})$.

\begin{tabular}{|c|c|c|c|c|c|c|c|c|c|}
\hline $\begin{array}{c}\text { Soil } \\
\text { reference }\end{array}$ & Amendments & Mean $\mathrm{pH}$ & SD-COV $(\%)$ & $\begin{array}{l}\text { Mean EC } \\
\left(\mu \mathrm{S} . \mathrm{cm}^{-1}\right)\end{array}$ & SD-COV $(\%)$ & $\begin{array}{l}\text { Mean } \\
\text { DOC } \\
\left(\mathrm{mg} . \mathrm{l}^{-1}\right)\end{array}$ & $\begin{array}{c}\text { SD-COV } \\
(\%)\end{array}$ & $\begin{array}{c}\text { Mean Cr } \\
\text { concentration } \\
\text { in the soil } \\
\left(\mathrm{mg} \cdot \mathrm{kg}^{-1}\right)\end{array}$ & $\begin{array}{c}\text { SD-COV } \\
(\%)\end{array}$ \\
\hline B1-1 & UNT & $7.12 \mathrm{NS}$ & \multirow{4}{*}{$0.15-2.08 \%$} & $1114 \mathrm{NS}$ & \multirow{4}{*}{$214.7-18.31 \%$} & $15.93 *$ & \multirow{4}{*}{$4.01-7.75 \%$} & $15.97 * *$ & \multirow{4}{*}{$0.98-6.30 \%$} \\
\hline B2-8 & UNT & $7.31 \mathrm{NS}$ & & $1230 \mathrm{NS}$ & & $14.34 *$ & & $16.21^{* * *}$ & \\
\hline B3-15 & UNT & $7.28 \mathrm{NS}$ & & $917 \mathrm{NS}$ & & $21.74 *$ & & $15.81 * *$ & \\
\hline B4-10 & UNT & $6.99 \mathrm{NS}$ & & $1430 \mathrm{NS}$ & & $24.32 *$ & & $14.07 * *$ & \\
\hline B1-2 & CPM & $6.98 \mathrm{NS}$ & \multirow{4}{*}{$0.27-3.67 \%$} & $1018 \mathrm{NS}$ & \multirow{4}{*}{$122-14.24 \%$} & $27.08 *$ & \multirow{4}{*}{$4.50-5.44 \%$} & $14.67 * *$ & \multirow{4}{*}{$0.34-2.31 \%$} \\
\hline B2-5 & CPM & $7.60 \mathrm{NS}$ & & $884 \mathrm{NS}$ & & $20.64 *$ & & $15.03^{* * *}$ & \\
\hline B3-16 & CPM & $7.46 \mathrm{NS}$ & & $771 \mathrm{NS}$ & & $25.85 *$ & & $15.15 * *$ & \\
\hline B4-11 & CPM & $7.26 \mathrm{NS}$ & & 754 NS & & $33.99 *$ & & $14.40^{* * *}$ & \\
\hline B1-4 & DL & $7.49 \mathrm{NS}$ & \multirow{4}{*}{$0.14-1.87 \%$} & $1654 \mathrm{NS}$ & \multirow{4}{*}{$308.3-24.79 \%$} & $26.34 *$ & \multirow{4}{*}{$4.14-6.96 \%$} & $17.16^{* *}$ & \multirow{4}{*}{$0.11-0.66 \%$} \\
\hline B2-7 & DL & $7.67 \mathrm{NS}$ & & $1000 \mathrm{NS}$ & & $25.76^{*}$ & & $16.98 * *$ & \\
\hline B3-14 & DL & $7.43 \mathrm{NS}$ & & $1013 \mathrm{NS}$ & & $26.52 *$ & & $17.13^{* *}$ & \\
\hline B4-9 & DL & $7.34 \mathrm{NS}$ & & $1308 \mathrm{NS}$ & & $38.46^{*}$ & & $16.93^{* * *}$ & \\
\hline B1-3 & DLX CPM & $7.45 \mathrm{NS}$ & \multirow{4}{*}{$0.32-4.46 \%$} & $1192 \mathrm{NS}$ & \multirow{4}{*}{$152.2-11.90 \%$} & $33.12 *$ & \multirow{4}{*}{$2.50-7.02 \%$} & $16.09^{* * *}$ & \multirow{4}{*}{$0.2-1.27 \%$} \\
\hline B2-6 & DLX CPM & $7.00 \mathrm{NS}$ & & 1347 NS & & $34.26^{*}$ & & $15.91^{* * *}$ & \\
\hline B3-13 & DLX CPM & $7.07 \mathrm{NS}$ & & $1457 \mathrm{NS}$ & & $29.16^{*}$ & & $15.93^{* * *}$ & \\
\hline B4-12 & DLX CPM & $7.59 \mathrm{NS}$ & & $1119 \mathrm{NS}$ & & $29.75^{*}$ & & $16.35^{* * *}$ & \\
\hline
\end{tabular}

* Significant for $\mathrm{p}<0.05, * *$ highly significant for $\mathrm{p}<0.001, \mathrm{NS}$ (non significant). 
Table 3. Selected inputs and output for ANN training (UNT=\#1, CPM=\#2, DL=\#3, DLX $\mathrm{CPM}=\# 4)$.

\begin{tabular}{crcc}
\hline Inputs & Level & Min value & Max value \\
Soil treatment & 4 & $\# 1$ & $\# 4$ \\
$\mathbf{p H}$ & 4 & 6.98 & 7.6 \\
EC $\left(\boldsymbol{\mu S . c m ^ { - 1 } )}\right.$ & 4 & 754 & 1654 \\
DOC $\left(\mathbf{m g . l}^{-\mathbf{1}}\right)$ & 4 & 14.337 & 34.260 \\
\hline
\end{tabular}

Cr concentration in the bean leaves (mg. $\left.\mathrm{kg}^{-1}\right)$ 
Table 4: Dry weight (g), concentration $\left(\mathrm{mg}_{\mathrm{kg}} \mathrm{kg}^{-1}\right.$ ) and mineral mass of $\mathrm{Cr}$ (g per pot) measured in the BL.

\begin{tabular}{cccc}
\hline Soil amendments & Dry Weight $(\mathrm{g})$ & $\begin{array}{c}\text { Cr concentration in } \\
\text { the plant }\left(\mathbf{m g . k g}^{-1}\right)\end{array}$ & $\begin{array}{c}\text { Mineral mass } \\
(\mathrm{g} \text { per pot })\end{array}$ \\
\hline UNT & $0.087 \pm 0.04$ & $1.438 \pm 1.23$ & $0.094 \pm 0.03$ \\
CPM & $0.112 \pm 0.02$ & $0.733 \pm 0.08$ & $0.083 \pm 0.01$ \\
DL & $0.122 \pm 0.02$ & $0.588 \pm 0.17$ & $0.069 \pm 0.00$ \\
DLX CPM & $0.103 \pm 0.00$ & $0.652 \pm 0.012$ & $0.067 \pm 0.01$ \\
\hline
\end{tabular}


Table 5. Comparison between averaged measured and ANN predicted values of $\mathrm{Cr}$ concentration in the bean leaves for the four soil groups. The determination coefficient $\mathrm{R}^{2}$ is based on the eight experimental samples kept for validation.

\begin{tabular}{|c|c|c|c|c|c|c|c|}
\hline \multicolumn{2}{|c|}{$\underline{\text { Soil (UNT) }}$} & \multicolumn{2}{|c|}{$\underline{\text { Soil (CPM) }}$} & \multicolumn{2}{|c|}{$\underline{\text { Soil (DL) }}$} & \multicolumn{2}{|c|}{$\underline{\text { Soil (DLX CPM) }}$} \\
\hline Measured & $\underline{\mathbf{N N}}$ & Measured & $\underline{\text { NN }}$ & Measured & NN & Measured & NN \\
\hline 3.29 & 3.285 & 0.762 & 0.764 & 0.519 & 0.519 & 0.524 & 0.523 \\
\hline 0.748 & 0.746 & 0.709 & 0.710 & 0.775 & 0.773 & 0.819 & 0.820 \\
\hline 0.601 & 0.600 & 0.392 & 0.391 & 0.892 & 0.890 & 0.805 & 0.804 \\
\hline 0.661 & 0.662 & 0.498 & 0.496 & 0.618 & 0.616 & 0.781 & 0.780 \\
\hline \multicolumn{2}{|c|}{$R^{2}=0.9998$} & \multicolumn{2}{|c|}{$R^{2}=0.9986$} & \multicolumn{2}{|c|}{$R^{2}=0.9989$} & \multicolumn{2}{|c|}{$R^{2}=0.9991$} \\
\hline
\end{tabular}


Table 6. Selected four inputs for the ANN prediction. Full factorial combinations generate 256 $(4 \times 4 \times 4 \times 4)$ data to investigate their effects on soil response.

\begin{tabular}{ccccccc}
\hline Inputs & min & max & Level 1 & Level 2 & Level 3 & Level 4 \\
Soil treatment & $\# 1$ & $\# 4$ & UNT & CPM & DL & DLX CPM \\
pH & 6.98 & 7.6 & 7.0 & 7.2 & 7.4 & 7.6 \\
EC $\left(\boldsymbol{\mu S . c m ^ { - 1 }}\right)$ & 754 & 1654 & 800 & 1100 & 1400 & 1600 \\
DOC $\left(\mathbf{m g . l}^{-1}\right)$ & 14.337 & 34.260 & 14 & 20 & 28 & 34 \\
\hline
\end{tabular}


Table 7. Correlation coefficients obtained by ANN and MLR methods.

\begin{tabular}{ccccccccc}
\hline Method & \multicolumn{2}{c}{ UNT } & \multicolumn{2}{c}{ CPM } & \multicolumn{2}{c}{ DL } & \multicolumn{2}{c}{ DLX CPM } \\
\cline { 2 - 10 } & $\begin{array}{c}\text { Training } \\
\text { data }\end{array}$ & $\begin{array}{c}\text { Training } \\
\text { data }\end{array}$ & $\begin{array}{c}\text { Training } \\
\text { data }\end{array}$ & $\begin{array}{c}\text { Training } \\
\text { data }\end{array}$ & $\begin{array}{c}\text { Training } \\
\text { data }\end{array}$ & $\begin{array}{c}\text { Training } \\
\text { data }\end{array}$ & $\begin{array}{c}\text { Training } \\
\text { data }\end{array}$ & $\begin{array}{c}\text { Training } \\
\text { data }\end{array}$ \\
Neural network & 0.999 & 0.998 & 0.998 & 0.996 & 0.998 & 0.997 & 0.999 & 0.995 \\
Linear regression & 0.876 & 0.695 & 0.792 & 0.702 & 0.765 & 0.637 & 0.882 & 0.802 \\
\hline
\end{tabular}

